\title{
FIBROCYSTIC DISEASE OF THE BONES. \\ BENIGN CYSTS, OSTEITIS FIBROSA, OSTEITIS FIBROSA WITH FORMATION OF TUMOURS AND GIANT-CELL SARCOMATA (VON RECKLINGHAUSEN), AND MOLLITIES OSSIUM WITH GIANT-CELL SARCOMATA.
}

By R. C. ELMSLIE, LoNDON.

BLoodgood. writing upon this subject in 1910, opens his paper with the statement that in many surgical lesions technique is ahead of diagnosis. This statement undoubtedly contains a very important truth. The diagnosis of these obscure bonc conditions is difficult, and at present uncertain; to many surgeons the very existence of bone cysts and the allied conditions is actually unknown: and this ignorance has led to the performance of operations of a magnitude which is not justified by the lesion present. In Germany, more particularly. another extreme has been reached. The number of cases placed upon record of bone cysts, ostcitis fibrosa, etc. is very great. Fach dissertation upon the subject contains, as a rulc, an elaborate pathological description of the specimens obtained, and a survey of the literature. But these investigations, valuable as they are, have been largely pathological. and have failed to classify the diseases upon any clinical systcm; and so they have not led to the record of a clear clinical picture which might assist subsequent observers in making a diagnosis. It is just this clinical picture

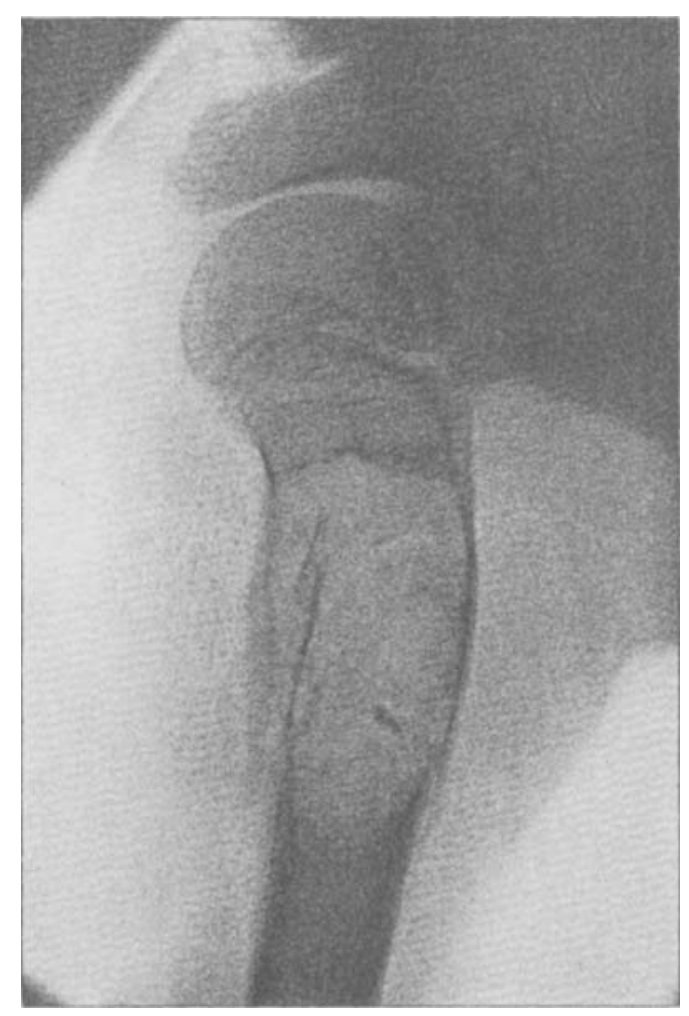

FrG. 12.-Radiograph of the humorus of E.O. at the time of the fracture. (Page 21.) which is wanting, and which the wealth of material at our disposal ought now to enable us to establish.

The history of solitary eysts of the long bones may be dated from the description in $\mathbf{1 8 7 7}$ of a cyst in the upper end of the humerus found by Virchow 
in a woman aged 56 . and ascribed by him to the degeneration of a chondromit. This thcory of origin was accepted by subsequent German observers. apparently led by the authority of their great pathologist. mintil 1901. when Beck. in Amcrica. described two cases of eyst in the tibia to which he ascribed a traumatic origin. In 1904. at the Naturforscherversammlung at Breslau. in a discussion raised upon two cases reported by Habcrcr. an acute difference of opinion arose. ron Mickuliez elaiming that these cysts. whether solitary or multiple, were duc to an innocent disturbance of growth of the bones; for this he suggested the nanc of Osteodystrophia cystica. At the discission at the German Pathological

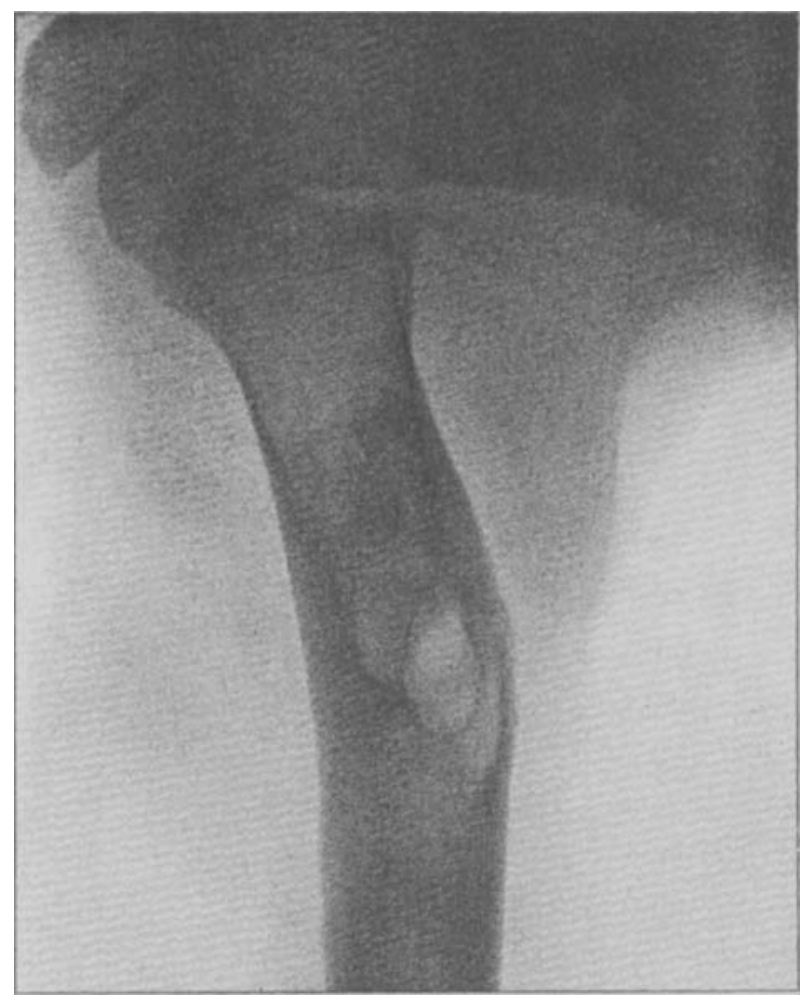

Fro. 13.--E. O. Eleven months ufter the fractur.

Society held in the same year, a further element was introduced ; this was the description by Mönckebcrg of two casc's: one of a solitary cyst in the humerus, the other of a diffuse discase affecting the humerus. clavicle. ilium, and fomur. with rysts, and with changes in the surrounding bone and marrow; these two cases he described as instances of the deforming or fibrous osteitis which had been previously described by von Recklinghausen. In the discussion which followed. opjinions were very divided. Some ascribed cysts in bone to new growths, cither to enchondromata or to giantcelled sarcomata; others held to Mönckebergr's theory : others to von Mickulic's. At a further discussion held at the Gorman Surgical Congress in 1906. although there was a similarly divided opinion, it became evident that it was impossible to class all bone cysts as of the same sort and origin.

It will be scen that at this stage several conditions other than simple solitary eysts had inevitably been drawn into the discussion. In the first place it had become impossible to differentiate strictly between single and multiple cysts. In the second place it had been shown that the tissuc around the cysts contained various elements, including cartilagc, fibrous tissue, fibrocartilage, bone showing absorption by ostcoclasts and formation by ostcoblasts, osteoid tissuc-due 
possibly to formation of new bone which had not properly ossified. possibly to disappearance of the lime salts from the older bone (halisteresis), - and sometimes collections of giant cells in a spindle-celled stroma which closely resembled myeloid sarcomata. In 1891, in a lengthy paper upon "Die fibröse oder deformirende Ostitis." von Recklinghausen had previously discusscd conditions in the long bones in which there occurs a fibrous transformation of the marrow. with the formation of new bonc, alssorption of old bone, deposit of cartilage. and the development of cysts and giantcelled sarcomata. Von lRecklinghausen placed these cases. which differed from cach other widely in clinical features: in the sanc category with Paget's osteitis dcformans. It is clear, howcver, that whilst there were certain pathological similaritics, the clinical picture of Paget's disease is so regular and well defined that this condition ought to be kept in a class apart. although cysts may arise in it as a minor pathological feature. Zicgler, in 1878, had called attention to the occasional derelopment. in osteoarthritis, of sinall cysts in the bones in the neighbourhood of the discased joints. Cysts resulting from myxomatous degeneration in enchondromata in the phalanges had been recorded by various observers. And finally, in 1910, Bloodgood showed conclusively that mycloid sarcomata may be treated by simple curctting---as if they were simple cysts-with a permanently successful result. thus showing that it was not impossible that some of the eysts in bones result froin myelomata.

The present position. therefore, may be thus stated. Cysts occur in many of

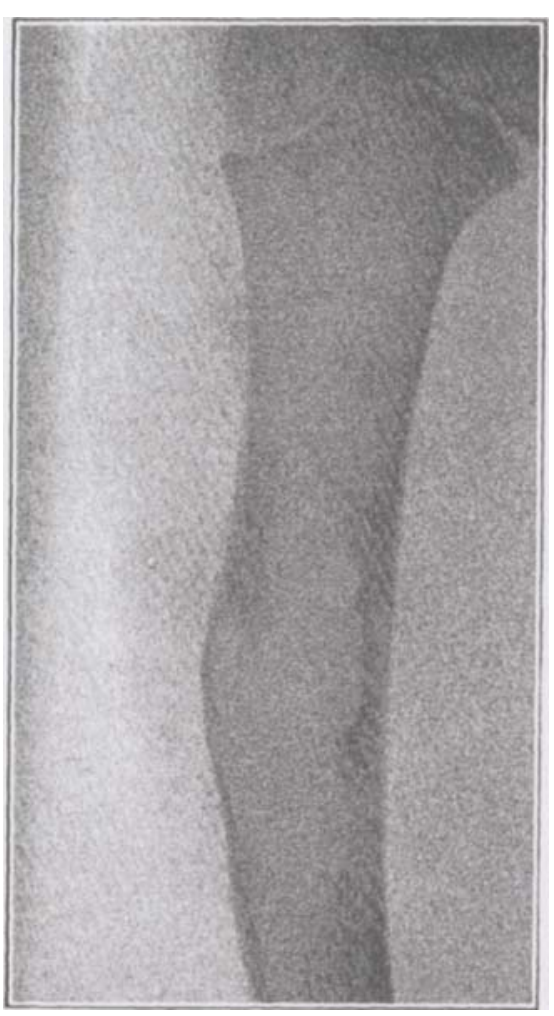

Frc. 14.-E. O. Throe yeurs after the fracture. the long bones, as well as more rarely in the skull and small bones. They may be single or multiple. They may be simple or surrounded by an area of diseased bonc. the latter often showing the conditions usually described as osteitis fibrosa. They may occur in other conditions, such as Paget's disease. osteomalacia, and osteo-arthritis. They may also result from the degeneration of cartilage tumours and of giant-celled sarcomata. In addition, they may result from the breaking down of true sarcomata; and they have been recorded by Frangenheim in callus at the seat of a fracturc. An investigation of bone cysts is therefore a very complicatcd undertaking, involving a review of a large part of the pathology of morbid conditions in the bones. Such a pathological investigation is rendered even more difficult by our comparative lack 
of knowledge of the significance of microscopic changes in the bones. It is this fact which has apparently led so great an authority as von Recklinghausen to group together rickets. osteomalacia, osteitis fibrosa. osteitis deformans, and bone cysts in one pathological category, in spite of the differences in their clinical history. It scems to be time that an attempt should be made, upon

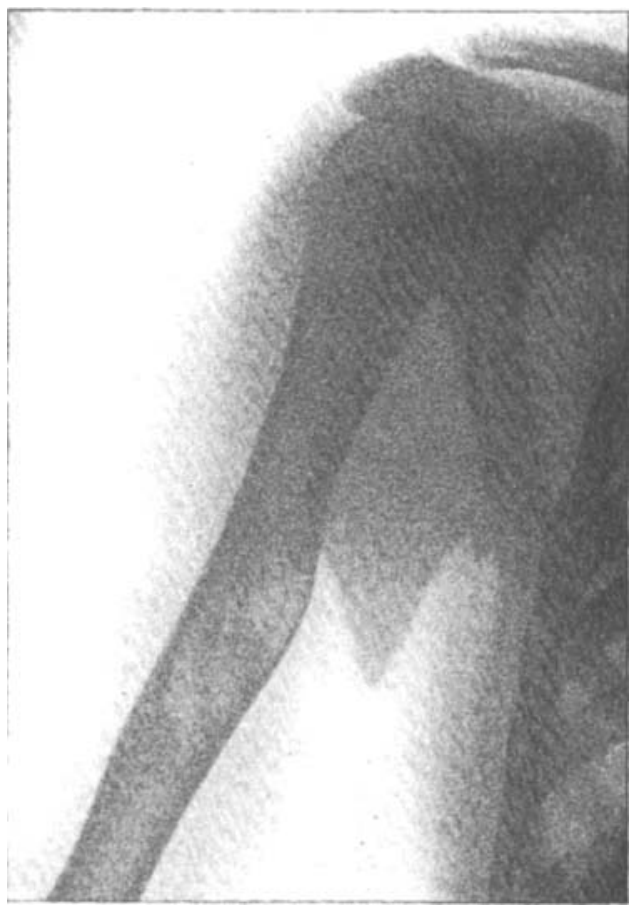

Fic. 15.--E. O. Four years and nme months nfter the fracture.

an attempt will be made to establish certain clinical types. In such a classification it is incritable that rare and isolated cxamples must be omitted or passed over rapidly-to await more exact definition later on, as records incrcase in number-attention being called rather to thosc conditions of which many examples have been already recorded. Diseases (such as Paget's ostcitis deformans, and puerperal osteomalacia) which are alrcady well recogniized and defined, will be omitted, as well as cysts arising in callus. in osteo-arthritis. in frank myeloid sarcomata, and in true sarcomata-execpt in so far as these are of importanec in diagnosis, or assist in elucidating the origin of cysts in the bones in general. clinical as well as upon pathological grounds, to sort out some of the medley of cases on record, to attempt to form some clinical picture or picturcs which nay guide futurc observers to a correct diagnosis and assist them in treatment, and to allow the interesting speculations as to the pathological relationship of these various conditions to occupy a secondary place for a time. In such an attempt. it appcars that a classification of cysts and allied conditions according to their site, rather than according to their macroscopic or nicroscopic characters, would be useful. In the following description, such a classification will therefore be largely adopted, and

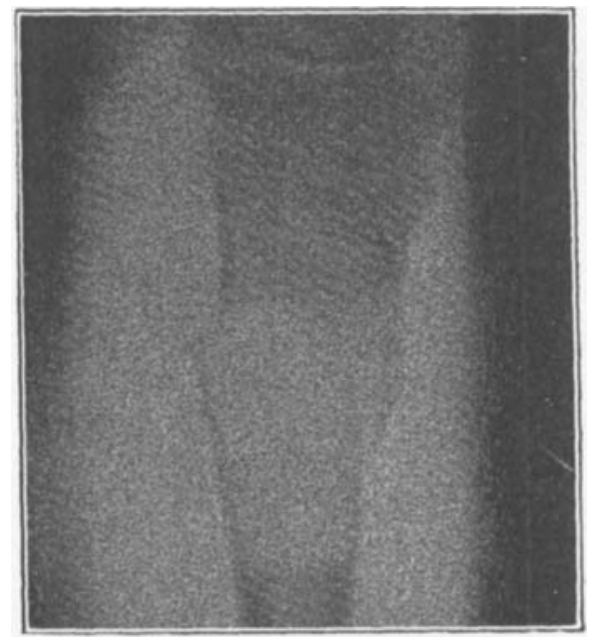

Fra. 16.-C. R. At the time of the fracture. 


\section{FIBROCYSTIC DISEASE OF THE BONES}

Silver, classifying 97 cysts of bone according to their sitc. found the following distribution :-

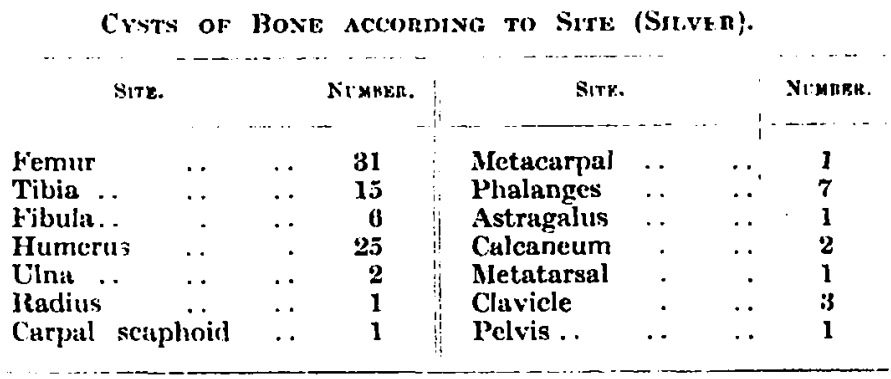

Whilst this list is by no means exhaustive-in particular. it takes no account of the skull-and whilst it also fails to indicate in how many of the cases there were multiple cysts. it still gives a good idea of the relative frequency with which the several bones are affected. and will serve as a basis of classification.

The complete literature of these subjects is now so large that it is practically impossible for a single investigator to consult all the rcferences. In the following account the cases eited. although numerous, are not intended to constitute a complete list; so far as possible, however. they have been selected in such a way as to be representative of the more frequent lesions.

\section{AFFECTIONS OF SINGLE BONES.}

Humerus. - Virchow's classical case, alrcady referred to, consisted of a cyst found post mortem in the upper end of the humerus of a woman, aged 56. Upon the ground that small masses of cartilage were found in the bonc in the neighbourhood of the eyst, this author ascribed it to the breaking down of an cnchondroma. Cysts in this situation have been recorded by many observers. The following threc cases, originally recorded by the author in the British Medical Journal in 1912, well illustrate this particular class.

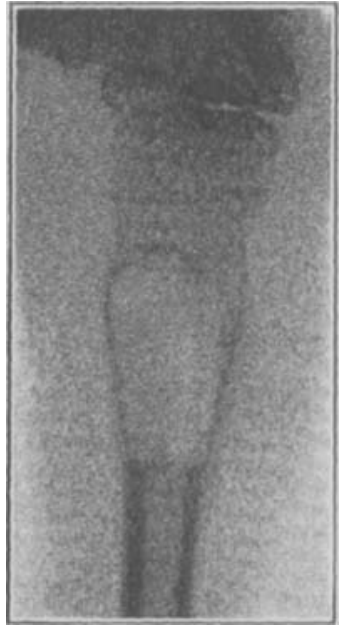

Fro. 17.-C. R. One month after the fracture.

E. O.. a boy, age 9. on May 12th, 1909. fell and fractured his right humerus inmediately below the surgical neck. A skiagram taken in the ordinary routine showed that the fracture had occurred through a cystic space in the bone. There was slight uniform expansion of the bone. the upper limit of the space being $\frac{s}{4}$ in. bclow the epiphyseal line : the outline of the cavity was sharp, the bone around not sclerosed ; a clear thin shell of bone covered the cavity except where interrupted by the fracture. and the cavity itself was not divided by trabeculas.

A diagnosis of endosteal surcoma was made, and on May 2f an exploratory operation was performed. On removing a portion of the outer wall of the cavity, the latter was found to extend vertically for about 2 in.; it contained a little viscid bloodstained fluid. The interior was scraped, a little soft tissue coming away. A frozen

VOL. II.-NO. 5. 
section. cout inmediately. slowed spicules of bone surrounded by onteochasts, with large intervening aroas of young and cellular tibrous tissue. Linfortumately no permanent sections were made. The wombl healed well; no splint or ufter-

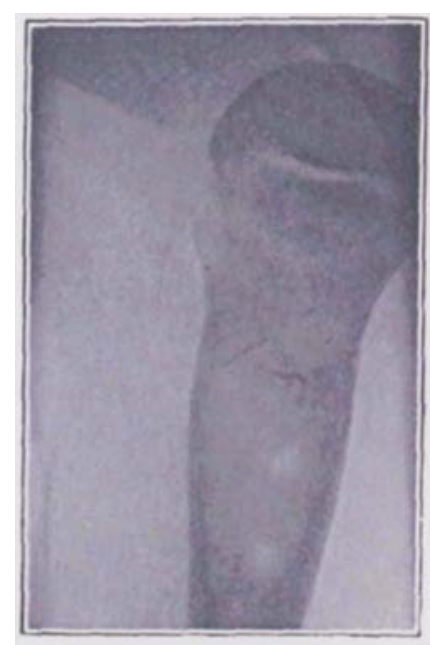

FIt. 18.-C'. R. Six weeh, ufier. the sractive.

traitment except massage was udopted.

I year later the arm was st rong and well : the humerix could still be lelt to be expanded at the sitc of the disease. The skiagram showed that there was still a small cystic space. chietly on the inner side. and that the bone around was scilerosed.

In May, 1912, thrce yenm after the friceture. a skiagman showed that the eystic spuce was larger and nore central in poxition: the sclerosis around was slight : the upper margin of the cyst wax now ubout 2 in. From the epiphiseal line, so thut it has been considerably displaced downwamls by growth.

In lebruary, 101t. the cyst had moved still further fown the shaft of the humerus, there heing :3 in. between the epipluseal line and its upper margin. The erst liad pollarged slightly, aul Hoe walls were thin. The Wassermann reaction was negattive. (Sice Figs. 1:-15.)

('. R.. a bos, age $\tau$. fell on November 28.1910. and fractured his left humertin just below llee surgrical neck. A skiagram showed the presence of : cystic space. similar in all respects to that founct in the previous case. (In Decemler 15. the fracture having united. the cost was opened by the removal of a portion of its outer wall, and the intcrior courctted : practically nothing could be got anay. the eyst being lined by hurd houe. The wound healed quickly: and the arm was tregted by immediate nassage and movement (Fig. 16).

I skiagran take'n oll January 2. 1011, showed abumant callus formation under the periosteum and some sclerosis mbove the (-ist (Fig. 17).

These changes were nore evident by .Jamary is. at which date the new periosleal bone was sullicient to produce an apparent expansion thercof (Fig. 18). Hy. December 20). 1011. A small space Was still present on the inner sidc of the hone. with a little expansion of the bone and all appearance of trabeculation of the $1 \cdot$ st. There was comsiclerable sclemsis of the bone on the outer sicke of the cyst at the point at which the wall had hech removed (Fig. 10).

In a skiagram taken on May 2t. 1912. (rightecn montlis after the operation, the ryst liad conlarged : its ирper murgin whs mow 1 in. furlher from the eppiplusiseal line than it was in the lipt skiagram.

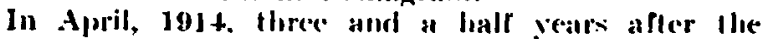
fracture, the cyst had moved further down the slabl. the disfance of its upper margin from the epipluseal line being now 2! in.: it had collarged, und its inner wall appeared thin. The Wastermann reaction was megrtive (Fig. 20). On April 18. 191t. the eyst was re-spened from the onter side. A thick. firm miler wall was fommel: the cystic space was of considerable size, contained brown flud. and conmmusated diverbly with the medullary avity above and below. A little soft. white tisste was removed by curcting.

Microseopic exumination of tlac tissue removed showed tragnents of bone. some of which were unealeilied: in one place a pices of normal l:ome was found partially 


\section{FIBROCYSTIC DISEASE OF THE BONES}

surrounded by decalcified bone. Snall fragments of spindle-celled tissue were also found, and these contained many pigment granules und some giant cells resembling osteoclasts: the latter tissue was similar to that of a myeloid sarcoma, but the giant cells were scarcely stifficiently numerous or large enough to enable one to diagnose the tissue as being a myeloid sarcoma (Fig. 21). The pigment granules consisted of altered blood pigment.

A. S., a boy, age 14, on September 12, 1910. broke his right humerus in throwing an india-rubber ball. A skiagram showed a cyst at the site of fracture, just above the insertion of the deltoid.

The cystic space in this case showed slight evidence of trabeculation. otherwise it exactly resembled the other cases; the upper margin of the space was about 1 in. below the epipluyseal line. The cyst was not explored, but the splint was kept on and the arm massaged for six months; a good strong arm resulted.

A skiagram taken on September 26 showed abundant periosteal callus. One taken a month later showed good union, with an apparent expansion of the bone, and sclerosis around the cyst. By November 9 the cyst showed a definite trabeevlated appearance, as it bone trabeculse had grown into the cavity from the impacted fragments. In March, 1911, this appearance was atill more evi-

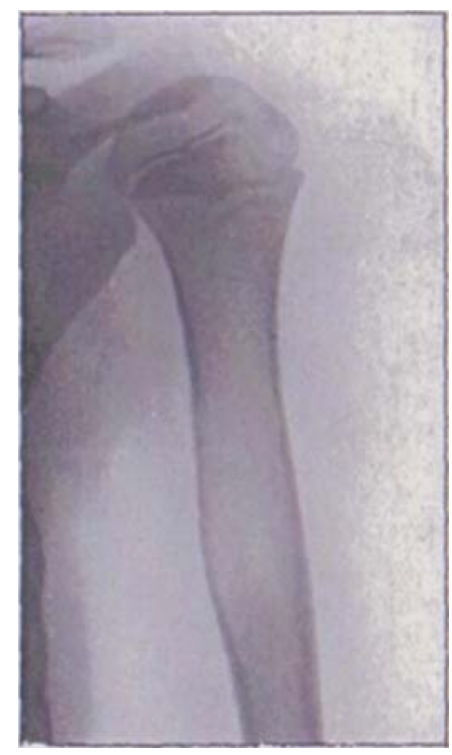

Fie. 20.-C.. R. Throe and a half years afier the fracture.

dent. By September, 1911 , one year after the fracture, the bone showed a moderate

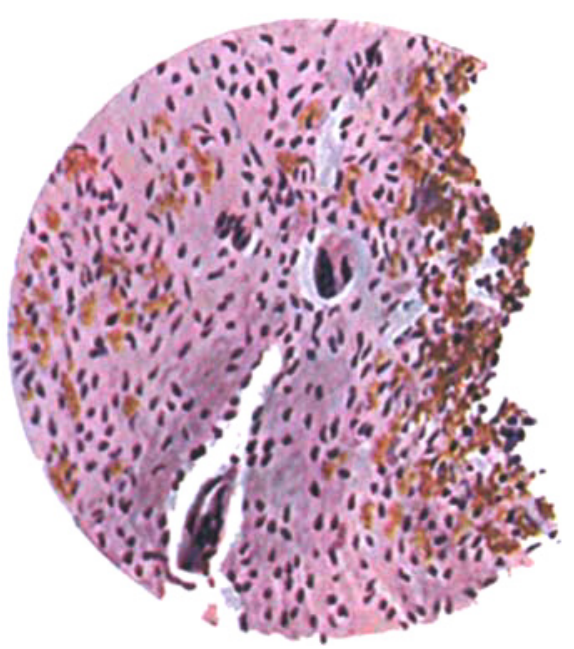

F16. 21.-- $\therefore$ R. Vicrosropic seetion of $n$ fragment of tistue removed from the interior of ihe cyat at the meond operation. The tiasue is for the most part spindlo-colled. but contuinx a lew giant culls and numbrous gramules of blood pignient. expansion, there being now little sclerosis, and the cystic space being apparently subdivided by trabeculic of bone (Pigs. 22-25).

An attempt to trace this patient in $191+$ Iailed.

At a discussion at the Royal Society of Medicine, upon the occasion when the first of these cases was shown. Sir Alfred Pearce Gould mentioned a similar case in a boy, in whom, after an injury, a ryst in the upper part of the hunierus was discovered. diagnosed at first as a sarcoma. Exploratory operation showed the correct dinguosis. The cyst was curetted. no lining membrane being renorible. A good result consued. Upon the same oceasion. Mr. Lockhart Mummery relnted the case of a girl, age 8 , in whom a (') st of the upper end of the humerus was thought to be a sarcomn, and the arm amputated. The cyst wall was found to consist of fibrous tissue.

Many other cases of single cysts in this situation have been recorded, of which the following will scrve as examples. 
24 THE BRITISH JOLRNAL OF SURGER

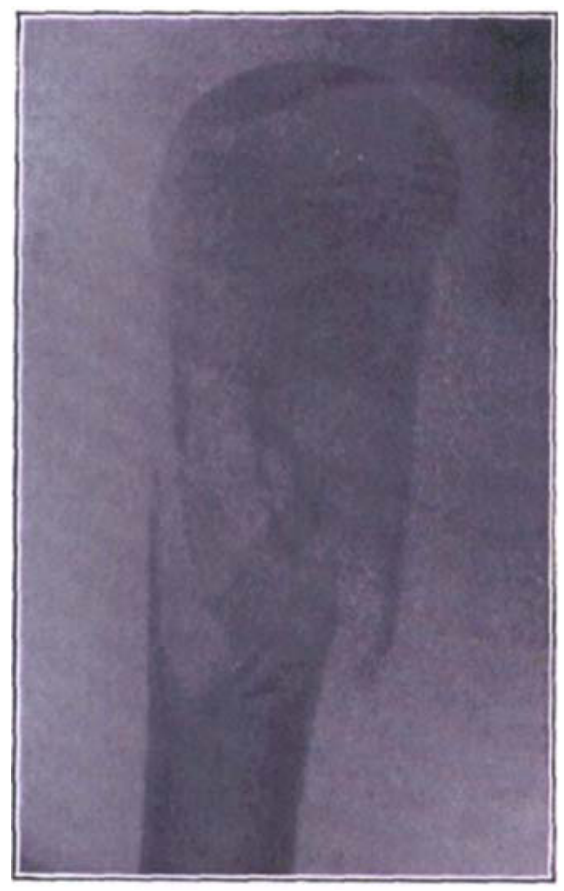

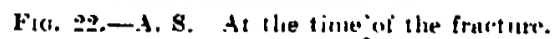

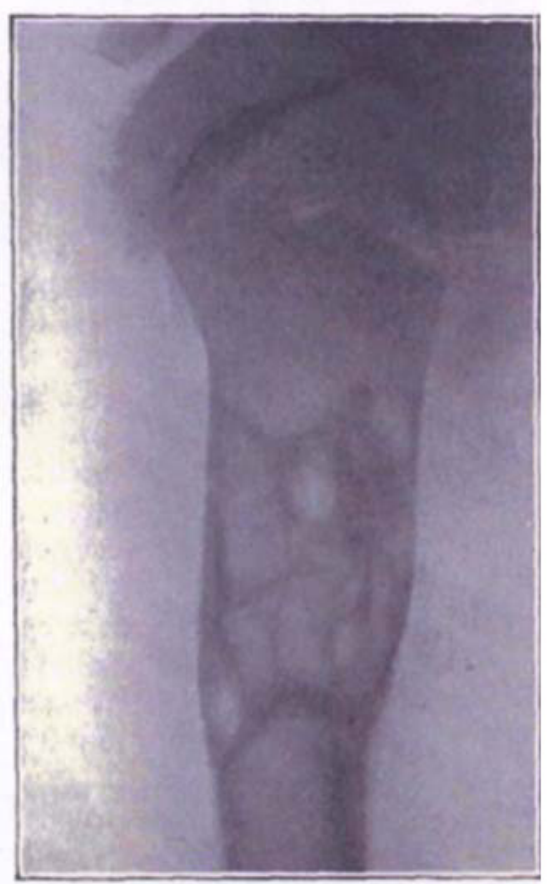

lif:. :4.-A. S. Six months after the hatertite.

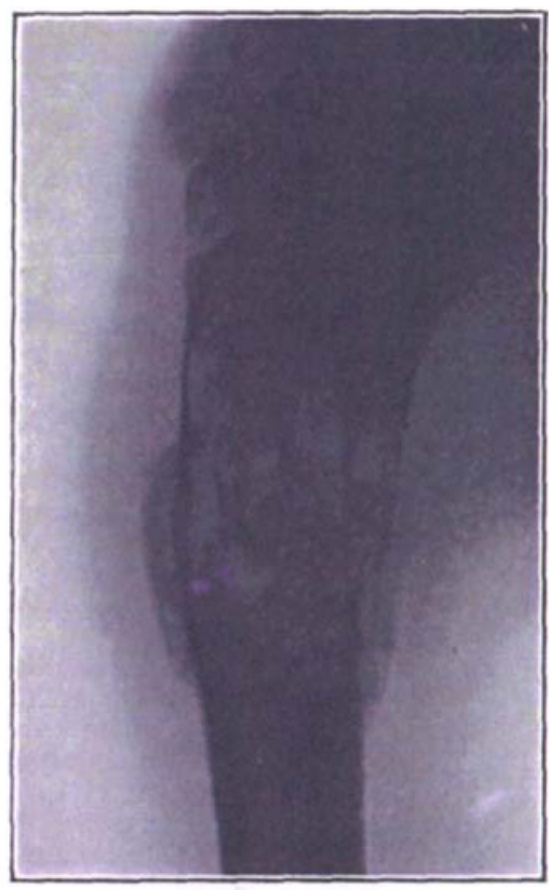

Flu: 23.-A. s. Fourteen days after the fracture.

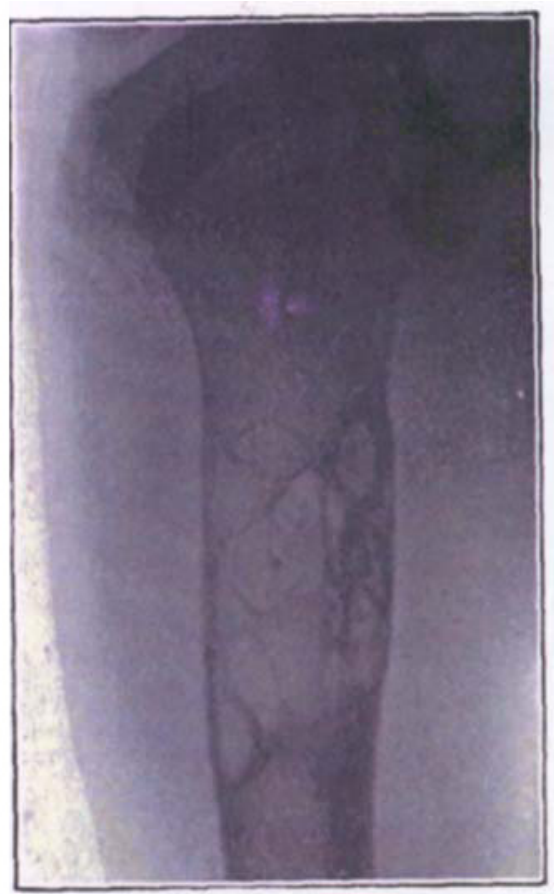

Fis. 25.- -1. s. Seventeen monthe atter the firallute. 


\section{FIBROCISTIC DISEASE OF THE BONES}

A girl. age 7 . fractured her lhumerus, which united, but was left weak. When 12 years old the bone was again fractured, and a cyst was then found involving, and causing kwelling of, the whole shaft of the bone. The cyst was opened and curetted, with a goot inmediate result. Sonnenburg considered this to be ase of cystic degenerution of the whole skeleton in spite of the fact that, as fur as he ascertained, only one bone was affected. (Sonsensurt:.)

Two cases of cyst of the humerus were reported. one at the uge of 20 , the second at the age of $t$ : iil the Iatter the cyst was opened and packed : two years later no sign of it remained. (Vo. Nickticz.)

A woman, age 25. had sultered an injury to the arm one and a half years before : there wus sev'cre pain and swelling. which passerl off in the course of Hve weeks. Some montlis later the pain recurred, and an enlargement of the bone appeared. The upper part of the humerus was resected under the impression that there was a xarcoma. The bone removed was beset with lange and sumall eysts, for the most part with sinootli walls. Around lhese the cortex was in some places reduced, in come places thickened. At the lower part of the speecimen was a small fibrous patch containing a tiny crutral cavity. Microscopically. anound the cysts there were foumd a transforination of the inarmow into a viscular fibrous tissuce, patchey resembling myeloid sarcoma. and definite evidence of the fommation of new bone by osteoblasts. (Börrich'H l:R.)

A boy, age 12. suffered from a spontaneous fracture, which was apparently at first inconiplete, but was completed b!' a fall a week later. A cyst was found in the upper part of the shaft of the humerus, its upper margin reaching to within a distance of about 2 in. Irom the epiphyseal line. T'liis cyst was opened and curetted. a mass of white homngenenus liwsue being removed. Eighteen months later the arm was useful. and a radiugraph showed no sign of the cavits. Mlicroseopically, the material removed consisted chiefly of fibrous tissue, in jart well tormed, in part containing abundant spindle-shaped nuclei, in part resembling cellular granulation pissue. In it were enibedded palthes of osteoid tisstle. nowliere properly calcilied : this showed evidences of deposit by oxteoblasts and of absorption by osteoclasts. (Vox Brt'sN:;

In a boy, age 1t, a cyst $11 \mathrm{~cm}$. long was found in the upper end of the humerus ; it daterl from an injury at the age of 10 . Its upper margin was within 1 (an. of the epiphyseal line. The upper 14 coll. of the shaft of the humerus was resected and replacerl by a grait from the fibula. The graft took well, and at the eucl of four montlis the arm was useful. Microxeopically, the wall of the eyst showed erliular fibrous tissue: in it, and in the metaphysis. were cartilage islands. The surrounding bone showed absorption by oxteoclasts. (Lexi:R.)

A girl. age 18. had sulfered from pain in the arm since an accident at 13. There was some swelling. A cyst involving the upper half of the humerus was found, and 21 ('II. of the humeris was resected and replaced by a graft from the tibia. A good result eusucd. The cyst had a comnective-tissue lining, contmining blood-pigment and cholesterin cristalis and some giant cells. There were no signs of cartiluge or of sarcomatous gruwth. (BR.sen.;

A rast involving the upper third of the hunerus was found in a girl, age 13 . There had been fractures at the ages of 8 and of 114 . which united well but left some swcelling. T'he cyst was curetted, the result six months luter being good. The cavity rontained reddish-grey gelatinous maxses, in which were spicules of bone. Microscopieally, these showed fibrous tissue, (art ilage. giant cells. and hamosiderin erystals. (ANischt'T\%)

A girl. age 6. had pain and swclling after an injury to the arm. Four weeks after the injuly, a fracture through a cyst was diagnosed by a radiograph. The esst was opened anil curetted. the fracture being completed in order to correct a deformity. which had nrisen. Good union resulted. T'he crst ocrupied about two inches of the shaft of the humerus, there being a narrow interval between it and the epiphyseal line. 
It was lined with fibrous tissue and with some granulation tissue. Some foreignbody giant cells were found around spaces thought to have been oxeupied by rovistals. There were a few bone tmbecula, some surrounded by osteoblasts; no cartilage was scen. (Snmoss.)

I girl. age 14. had fractured hor humerus the day before. A cyst was seen in the radiograph, its upper margin being about an inch below the epiphyseal line. It was opened and packed, healing by grunulation. It was lined with a thin

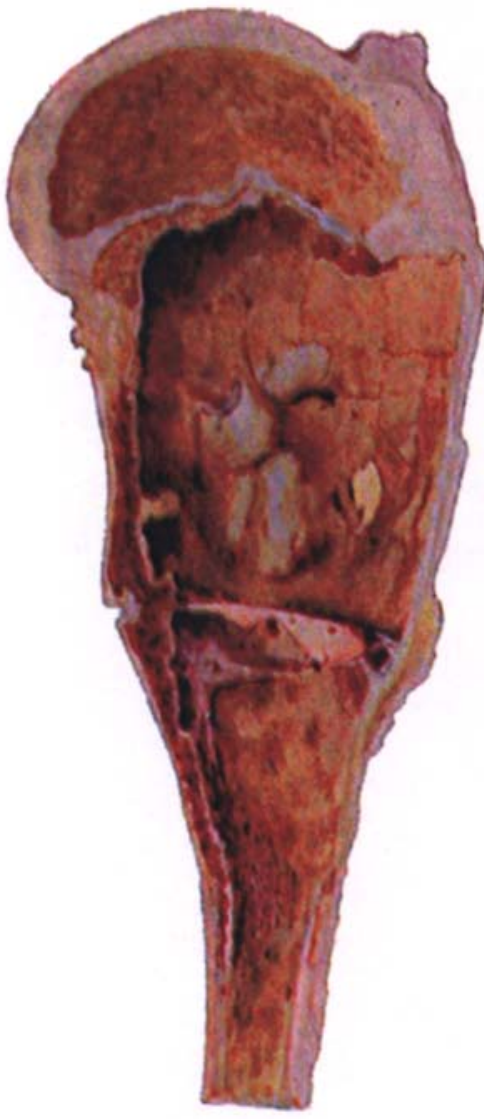

Fll: zti.-cyot of the mper end of the aliaft of the liti. melux. (Powal college of sinrorums' Werewm. Siperimen lliater) fibrous layer, which combined a few giant cells. (Rijpkil.)

A bov. age 7 , fracturerl his fumerus. A cyst was seen in the radingraph, occupying the upper third of the bone, and extending to within hall an incll of the epiphyscal line. Operntion was refused. Two yeurs later the arm was strong und useful. Röpke states that the expansion wiss no longer present, but the radiograpli reprodiced appears to slow the reyst still there. (Köplis.)

A boy, age 12. Sractured his humerus through a cost uxon threc occasions. No operation was performed. After the last Iracture, the cyst, as far us conld be seen in skiagrams, ceased to progress. (II.ABERT.R.)

A womalı. aged 31, had suffered from pain in the arm for two ycurs before she fractured her humerus. A cyst was found oceupying the head and upper haif of the shaft of the bone. The greater part of the sluaft, including the upper exiremily. Was excised, and a part of the fibula successfully grafted. There was. however. persistent puralysis of the musculospiral nerve. (II.1uknkik.)

A boy, age 13, had twice fractured the humerts through a cyst. 'Tlue upper part of the sliaft was excised subperiosteally. The botie was replaced b5 an e-bons rod: it re-formed in the coutuse of two nionths. and left a good arm. Lett gives a very carcful description of the pathology of this eyst. his condusion being as follows:- - The formation of the cyst is ansociated with a local process which is in the nature of an inflammation. This process has led to bbrosis of the marrow: with destruction of old bone. and the formation of renent osteoid tissue. membrunc, and lamellar bone. 'The process is of long duration. The process has also led to the fomation of hyalime cartilage; or possibly the process has bcen provoked by the degeneration of an abnormal deposit of (artilage." (Ll:Tr.)

Bloodgood also mentions sereral cases of evests in this sit mation. He divides cysts into those which contain a lining membranc and these which do not. 'lhis distinction does not appear to he very real. Some of the eysts in the humcrus have a lining. some have not. yet the elinical histories and inicroscople pathology secm to show that all are of the same nature. Finther. in a case of crst in the femm which will be montioned later, silver found no mombrane at a first opcralion. Whereas at a serond opcration. a yenr and nine months later, there was a distinct fibrous lining. Bloodgood's cascs angec with those 


\section{FIBROCYSTIC DISEASE OF THE BONES}

alrcady described, in occurring in young prople who suffered from fractures; in two cases fractures occurred twice. All were curetted and gave good results. In two cases in which there was no lining, the bone around the cyst showed the changes of osteitis fibrosa.

7:3 The above list, although long. is by no means exhaustive; many other similar cases of rysts in the upper end of the shaft of the humcrus liaic been recorded. 'There are two excellent specimens of such cysts in the muscum of' the lioual College of Surgcons.

sperimen 1637e (Fig. 26). " A vertical section of the upper end of the hunerus of a child. 'The shaft for about the distance of $a$ in. is expanded into a thin-walled cavify. the lighest and broadest part of which has a diameter of 1 in. and accurately corresponds with the epiphyseal line, except at the inner aspect. where a sull wedgeshaperl area of nomal cuncellous bone of the upper end of the diaphysis remains. The interior of the cavity is quite smooth, though here and there the osscous shell brumling it is thimuer ihan elsewhere. and translucent. To certain of the low ridges or trabeculat belween the thimer spots. membramiform processes of soft tissuc are attached. The cavity in the recent stale contained a clear st rawcoloured fluid, in which nothing stuggeslive of luvdaticls was foumd.

.. The parts were removed by amputation from a boy, aged $\boldsymbol{\tau}$, who fell whilst rumming on level groumd. and complained of laving lium his left shoulder: examination showed notling abmormal. During the following seven montlos he was never able to use the arm quite freely. and complained of its liurting hiin if suddenly jerked. In . January. 100.). The jatient had a recond fall. and complained that he had hurt the arm in the same place. "I'be donor then found all emlargemcht of the upper third of the humerus. With some tendermess on firm pressilre: there was no redness or crelema. A skiagram confirmed the diagnosis of tumour. The limb

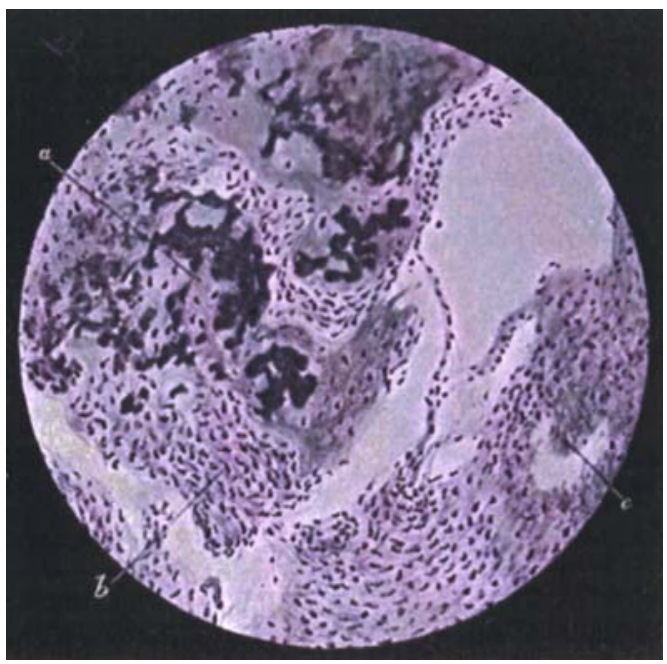

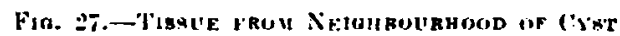
hown in Fig. 22ti. (a) Cartilage, the dart parls being calcitied: (b) Fibrous ti-alle: (r) Hialuoryluge. (l.ome purrer.)

Was removed hy Mr. Watson (heyne through the neck of the scaupula. Recovery was uncentful." (The above account is taken Irom the Muscum catalogue.)

Mlicroseopic sections of the wall of the (-yst (Figs. 27 and 28 ) show masses of cartilage. some of which is calcilied in its centmal part. The tissue between these masces of rartilage consists of fibrons marrow. Patches of ralcified lisicte appear in this librous marrow : in the section preserved in the museun there is no truc bone. but it is coident to the naked rye that llere is bonc in the cyst wall. Osteckelasts are not abmolant in this part; they lie chietly in the neighbourbod of the cartilage, sume of which appears to be undergoing absurption by their action. The tisite is very vascular. and there are some areas of hamorihage. A section of one of the: membramilom sepla (Fig. 29) shows it to comsist of spondle-celled connective tissue in which comsislcrable numbers of multimucleated giant colls occur. These are milomuly distributed, and have mo rebation to the extmasations of blood. Pig. menl grainules are abundant. 


\section{THE BRITISH JOURNAL OF SIRGERY}

The second specimen (62/1913) was presented to the Museum by Sir Jolin Rland-Sutton, who thus described the sase (Fig. 30).

*A boy, age 19. hurt his shoulder whilst leaving a motor-bus in motion. A

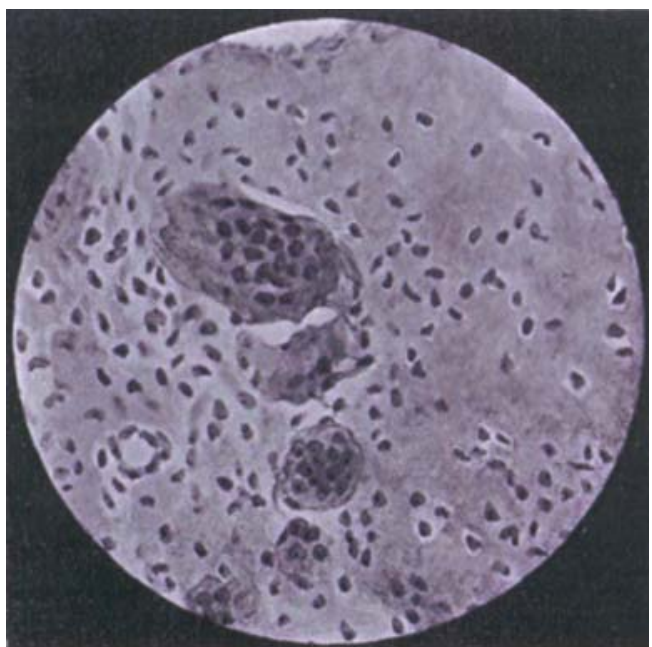

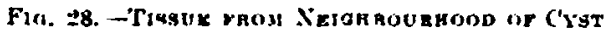
jhonil in $F$ ig. Ot. Showing giant cells in neighbout. lood of cariiluge.

skiagraph furnished evidence that the lummerus was fractured at the surgical neck; but the bone at the seat of the injury exhibited a shadow which suggested the presence of un endosteal surcoma. Ifter careful consideration 1 excised the upper third of the lumerus. When the exsected piece of bone was split longitudinally: the cancellous tissue of the bone immediately below the epiphysis was found lollowed out, and the irregular cavity filled with pink lluid. The recesses in the osseous boundaries of the ravity contained fibrous tissue and large multinuclear cells."

fircum such a scrices of cases as that collected abose, a very clear clinical pjecture may be constructed. cenabling us to diagnose a crest in the upper part of the luminerus with reasongble certaints. The patholosgical picture aho. although complicated, is almost miform. and chables us to describe and define the changes which take place. even if it leaves us in some doubt as to the name which we onght to apply to the condition.

Clinicel History. - A large proportion of the cases have orcurred in children. 'The carlient onsct was at the age of lonr rears; from that age onwards the rases arc fairly cronly dist ributed throughout childhond and adolescence. In Bitticher's and in one of Habcrer's cases, the srmptems arose in adult life: and in Virchow's case the cost was discovered post mortem at the age of 5t;. So that, although the condition is in the main a disease wi the growing period, it must be recognized that it may be met with at any age.

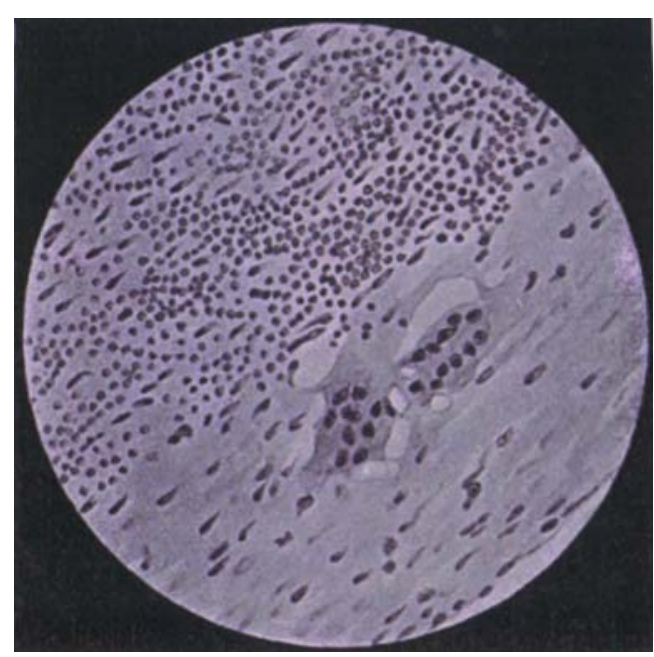

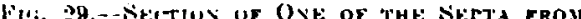

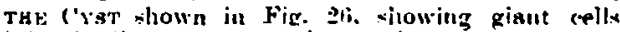
lying in fibous tixalle and hear them an ext lavnas. tion of isloud. (lligh poicer.;

In a very large number of case's the ryst has bech found in the examination 


\section{FIBROCYSTIC DISEASE OF THE BONES}

of a fracture of the upper part of the humerus loy means of a radiograph; this ore'urred in the writer's thrce cases. In several caces, owing to the fact that the first fracture was not thus examined, the crst remained undiagnosed, and re-fracture oceurred. Many of the fractures have apparently becn incomplete, so that they were not crident upon clinical examination. Next to fracture, pain and swelling are the most frequent symptoms. These may arise spontancously; more often they conce on after an injury. Some observers have on this account ascribed a trammatic origin to the cysts. It a ppears more probable that the injury has caused an incomplete fracture through a pre-cxisting cyst, and that pain and swelling have resulted from further enlargencut of the "avity. Deformity and disability of the limb have. as a rule, only beconce evident after an injury or al definite fracture. 'The onset, without previous injury, of much dirability, with muscular wasting. although possible in a cyst. ought to arouse suspicion that an culargencent of the humerus in this situation is due to some other condition.

Radiographic -tppearances.--In the majority of cases, then, the diagnosis will depend "1pon the discovery of a cystic condition at the site of a fracture. The eyst is usually ecentral in the bone. which it fills more or less completely. At the time of the fracture, the bone is usually a lit tle expanded and the cavity single, mot apparently loculated or crossed by trabeculae. But if the fracturc has oceurred at an carly stage, as in Bland-Sutton's case. the cyst miny not completely till the bonc, which may thins not be expanded at all, and there mat be some subdivision into loculi. Exicept as the result of healing of a fracture. these is ustally no sclerosis of

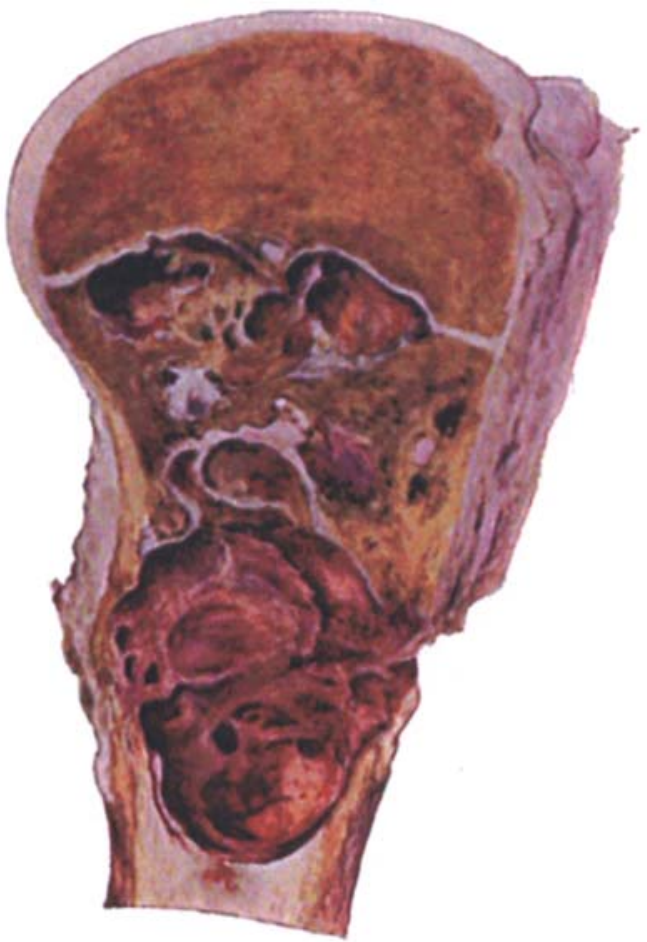

Fic. 30.-Cyat of the upper end of the hunerus. (Royal College of Surgeons" linseum. speciouen 6:, 1913.) the surrounding bone and no thickening of the periosteal bonc. Figs. 12, 16, and 22 may be taken as quite characteristic of the appearances in small eysts at the time of the fracture.

The erists rary greatly in extent; most often they arc (lose up to the II) per epiphiseal linc of the humerus and extend downwards for a distance of one to two inches; but they may reach a third of the way down the bone; and in Sommenburg s case the crst occupied the whole of the shaft. The upper end of the crst very often lies in close proximity to the epiphyseal line. But. as is well shown in Figs. 12 to 20 . growth at the epiphyseal line mores the cyst further and further down the shaft. It may therefore be assumed that a cyst which is found close to the upper end of the bone is of recent origin; 
one of the middle of the shaft is probably of older origin; and one which occupies the whole of the shaft has probably arisen early in life. and has continued to extend. Although in some cases the upper margin of the cyst has actually been formed by the epiphyseal cartilage, in no case does this appear to have interfered with the growth of the bone.

Differential Diagnosis.-In the upper part of the humerus, cysts are probubly more common than any other endosteal tumour. Secondary carcinoma may occur here, and give rise to difficulty in older subjects, more particularly if the primary tumour is not in an accessible situation. True endosteal sarcoma of the upper end of the

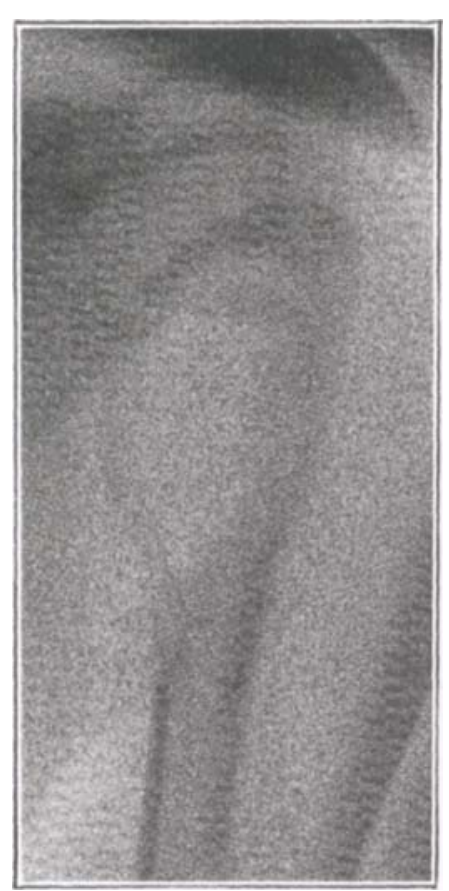

FIG. 31.-True sarcoma of the huneruy, showing expansion of the bone with great thinning of the bony shell upon the inner side. humerus is usually a very painful affection; the radiograph will, at quite an early stage, show that the tumour has expanded beyond the limits of the bone (Fig. 31). Chronic abscess and gumma of the humerus are also rare; they should be distinguished by the presence of periosteal thickening of the bone. An enchondroma of the upper part of the shaft of the humerus, described by Gask, closely resembled a cyst in the radiograph. In this case, however, swelling and disability occurred without any accident; and upon a careful examination it will be noted in the radiograph that there is somc sclerosis of the surrounding bone, and that the translucent area is subdivided by trabeculæ, and is not central (Fig. 32).

A careful consideration of the clinical history, physical signs, and radiograph, will enable the diagnosis to be made with considerable certainty; but in any case in which therc is the least doubt, an exploratory operation will settle the question at once.

Treatment. - In reviewing the recorded cases, it will be seen that the treatment has varied from complete inaction to amputation of the limb. In my third case, the bone around the cyst became much strengthened after the fracture; and, as far as could be judged by radiographic examination, the cyst itself became subdivided by trabeculx (Fig. 25); the arm was strong and sound seventecu months after the fracture. Haberer records a cast in which threc fractures occurred in the course of two years; after the last of these the cyst ceased to progress. Röpke watched a case in which operation was refused for two years; at the end of this time the arm was strong, and Röpke says that the expansion of the bone was no longer present : but the radiograph he reproduces appears to show a cyst. still there. Most of the cascs have been treated by opening and curetting the cyst, the wound being sometimes closed, sometimes packed and allowed to granulate. The functional 


\section{FIBROCYSTIC DISEASE OF THE BONES}

result from this treatment has been uniformly good. In many cases it is said that the cyst has completely disappeared. In my first two cascs in which this treatment was carricd out, the cyst in each case remained and even cnlarged, but the functional result was excellent; in these cases the wound was completely closed at the time of operation. In the second case the cyst was curetted a second time because it was enlarging.

In a number of cases resection of the affected portion of the humerus has been carried out, sometimes sub-periostcally, sometimes with the periosteum. In most of those so treated a portion of the fibula has been transplanted to fill the gap. Whilst, on the whole, these have been very successful, and have been useful in demonstrating the possibilities of bone transplantation, there can be no doubt that the operation is unnecessarily severe.

Amputation has only been performed as a result of mistaken diagnosis, or from a misconception as to the origin of the cysts.

The proper trcatment of these cysts of the humerus may, therefore, be stated to be curetting, although it is perfectly justifiable to watch a cyst for a time and see whether it progresses. The curetting should be thorough, and the medullary cavity of the bone should be opened above and below, so as to admit normal marrow into the cavity left. No accidents have occurred during the curetting of a cyst of the humerus. If there is any deformity, the humerus may be safely broken or cut through at the site of the cyst in order that the bone may be straightened.

Pathology.-The pathological changes found in these cysts of the humerus appear at first sight to be very various and contradictory; yet upon careful

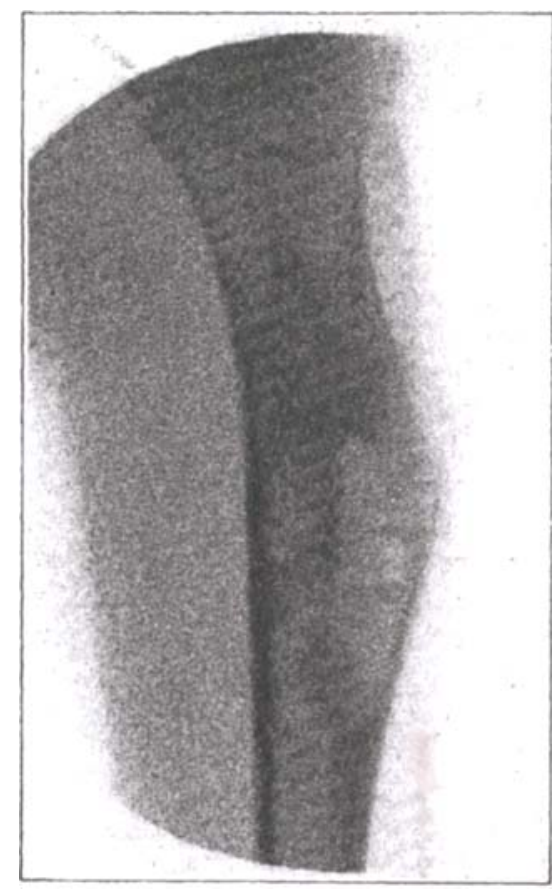

Fic. 32.-Enchondrome of humerus. (Gask's C'ase.)

examination they will be found to be really uniform, although complicated.

The contents are always fluid, varying from yellow to deep reddish brown in colour, sometimes clear, sometimes containing cholesterin crystals, which are probably the result of previous hamorrhages. In scveral cases this fluid has been cultivated; upon one occasion only has any growth resulted, and then only a white staphylococcus. Solid masses in the cyst are very rare; in my second case, when curetted for the second time, some solid particles were removed which possibly came from within the cyst; these consisted of a spindle-celled loose fibrous tissue containing some giant cells, and numerous pigment granules.

The cyst walls are by no means all alike. When a smooth wall exists it 
consists of well-formed fibrous tissue, which merges externally into a fibrous marrow. The latter replaces the normal marrow in the neighbourhood of the cyst. In this fibrous marrow, which occurs in the wall of all these cysts, whether there is a proper lining or not, there may be found bone, osteoid tissuc, cartilage, patches of calcification. giant cells, and hæmorrhages.

The bone for the most part shows active absorption by osteoclasts; in several cases it has been found to be surrounded by a layer of ostcoid tissue, bone which has either never been calcified, or else has been deprived of its calcium salts. There is usually also a certain amount of evidence of the deposit of bone by osteoblasts; and at the periphery there is always a thin residue of the normal cortex of the humerus.

The cartilage may be abundant, as in Virchow's case and in the specimen at the Royal College of Surgeons, but it occurs always in small patches, and not in a continuous mass such as one would cxpect to find in an enchondroma. It may bc hyaline, but is more often fibrous; it may be partly calcified. It, also shows evidence of absorption at the periphery by osteoclasts.

Patches of calcification, hremorrhages, and pigment granules (hremosiderin) are usually scattered in the fibrous marrow.

The giant cells form an important feature. For the most part they are undoubted osteoclasts and lie in close proximity to the bone and cartilage. But they are found also, either singly or in clumps, in the fibrous marrow, which may itself vary from fully-formed fibrous tissue arranged in firm parallel fibres, to a loose vascular spindle-celled tissue. The giant cells do not in the least resemble those found in tuberculous tissue, nor are they found specially in the proxinity of hremorrhages or patches of pigment. They resemble the osteoclasts, and there appears to be no reason to differentiate them from these. In places where there are collections of these giant cells in a spindle-celled stroma, the appearances closely resemble those of a myeloid tumour.

No evidence of myxomatous degeneration in the fibrous tissue or cartilage appears to have bcen noted.

'This pathological picture has been variously interpreted. Briefly stated, the possibilities appear to be the following :--

1. The cysts are derived from enchondromata by degeneration or by absorption of the cartilage by osteoclasts. This was Virchow's view.

2. They are derived from myelomata in which the bulk of the tumour formation has been absorbed, the surrounding changes being the reaction in the bone and marrow around.

3. They result from a form of chronic inflammation in the marrow, osteitis fibrosa.

4. They result from hæmorrhages into the bone, the other changes being secondary reactions in the marrow and bone.

5. They result from a perverted growth of bone and marrow, the balance between bone formation and absorption being disturbed, the osteoclasts taking on an excessive function, and the connective-tissue elements in the marrow developing to an extreme degree. Upon this theory the condition would be named ostcodystrophia cystica (with von Mickulicz), or a metaplasia of bone and marrow. 


\section{FIBROCYSTIC DISEASE OF THE BONES}

These cysts of the upper end of the humerus have been described at length, because they form so clear a clinical type, and serve as a good introduction to the much less common lesions of some other bones. Although, in the cases so far mentioned, these cysts have been solitary, cysts in this situation have occurred in association with similar pathological changes in other bones. These will be referred to later.

If the growth of the bone is allowed for, this type of cyst will account for all cysts in the humerus except those which have been found quite close to the lower end. These have been very few. Corson reports the following case.

A girl suffered from pain in the arm from the age of 17 onwards. At 18 she fractured the humerus by slight violence, the fracture uniting without the cyst being diagnosed. The pain continued, and at 21 there was an evident swelling. Corson's radiograph does not show the extremities of the bone, so that the relationship to the epiphyseal lines cannot be made out ; but there is evident expansion of a considerable part of the lower half of the shaft of the humerus. The cyst was explored, clear synovia-like fluid escaping. The cavity was $8 \mathrm{~cm}$. long, with a very thin bony shell. It was not curetted, but simply packed. Two years later the arm was strong; there was, however, a tiny sinus. The cyst wall presented a well-organized lining membrane, no active changes were evident, and Corson suggests that the condition was the result of an old osteitis, largely overcome, but at the expense of very extensive bone atrophy and impaired function. He also suggests that an attack of typhoid fever at the age of 15 might have been the cause. There appears to be no reason for separating this case from the last group.

[: "Mr. Raymond Johnson has kindly sent me notes of the tollowing case.

7 A. D., male, age 22. Admitted to University College Hospital on August 8, 1912. Six years ago he fractured the right humerus just above the elbow. In two months he could use the limb freely. Four and a half months ago he began to fail in health, and had a cough; he was said to be tuberculous, and was sent to a sanatorium. Two months ago the right arm began to be a little painful above the elbow, and the joint could not be completely straightened. A week ago, whilst taking hold of a banister to help himself out of a chair, he suddenly felt the arm give way and become quite useless. The humerus was found to be fractured, and a splint was applied.

Upon admission, the patient was thin, there were signs of consolidation at the left apex, very little cough, no tubercle bacilli found in the sputum, temperature normal.

There was a fusiform swelling of the right humerus just above the condyles; the bone was fractured through the middle of this. The upper end of the right radius was also enlarged by a painless, elongated, fusiform swelling. The left fibular malleolus was enlarged, and the foot somewhat inverted, as the result of a fracture at the age of 9. Radiographs showed cysts in the lower end of the shaft of the humerus and in the upper part of the shaft of the radius.

On August 14 the humerus was explored and found expanded into an indefinite cavity involving both fragments and containing blood-clot; it was surrounded by cancellous bone. The cavity was scraped. The radius was also explored, and a cyst found, the compact bone being reduced to a thin plate.

The fracture united firmly. Subsequent radiographs showed that the cysts in both bones were apparently filling in and becoming smaller.

Decken reports a further case of cyst in the lower end of the humerus in a boy, age 19, in whom a swelling in this situation arose four weeks after a fracture : I have not been able to obtain his paper. In Capt. Bradfield's case of multiple cysts, referred to later, there was also a cyst in this situation.

So far as these scanty records go, the cysts in the lower end of the humerus seem to agree fairly well in clinical type with those in the upper end of the bone.

vOL. II.-NO. 5 . 


\section{THE BRITISH JOLRNAL OF SLRGERY}

Clavicle.-The few cysts in the clavicle which have becn recorded appear to come definitely into the class of myelomata. König mentioned two such at the meeting of the German Surgical Society in 1906. There is an cxcellent specimen of such a tumour in the inuseum of St. Bartholomew's Hospital ( $471 d)$; it is labelled as follows.

" The outer third of the right clavicle, which has been laid open longitudinally to show great expansion of the bone due to a myeloid sarcoma. The cut surface shows that the bone is greatly thinned, and that the cavity is intersected by fibrous septa forming several cysts. In the cavity are to be seen old blood-clot and portions of soft growth.

"Removed by operation from a girl, age 6, in whom redness, tenderness, and swelling of the outer part of the clavicle had been slowly increasing during six wecks before the operation. There had been no pain. Recovery was rapid and complete."

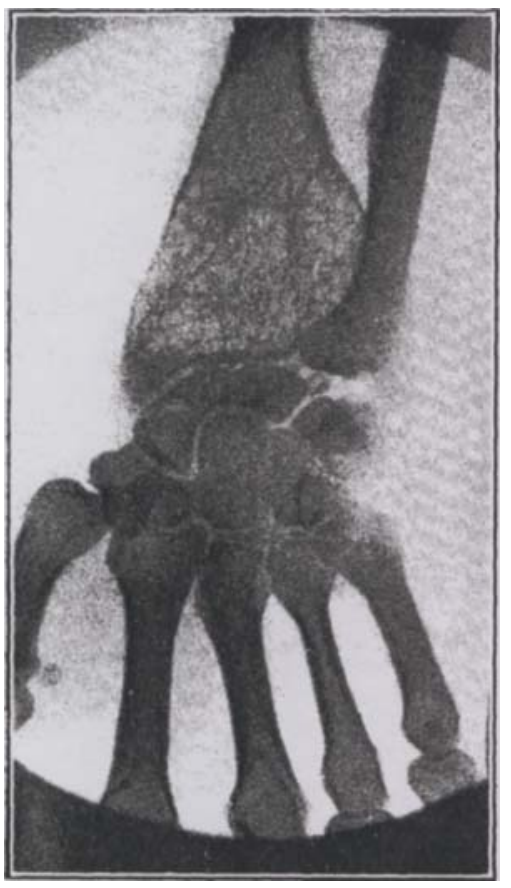

Fig. 33.-Myelome of radius.

Pflugradt, at the meeting of the German Surgical Society in 1912, showed a specimen from the following case.

It was taken from the clavicle of a girl, age 18 , in whom a cyst developed immediately after a traumatic-i.e., not pathological-fracture. The cyst was multilocular with a firm fibrous capsule. Microscopically, around the cyst were found the typical changes of osteitis fibrosa; in the central part, in the septa of the cavity, there was connective tissue with considerable masses of giant cells. Pflugradt considered that the difference between his specimen and a sarcoma lay in the changes in the direction of organisation found around the cyst.

This case, like sevcral others to which reference will be made later, appears to be intermediate in position between bone cysts and frank myelomata.

Ulna.-Cysts of the ulna appear to be very rare. G. D. Davis, at a discussion at the American Orthopædic Association in 1911, mentioned a case of cyst of the ulna in which, after breaking the wall, there being no lining membrane, there was found some blood-clot, while up in one corner there was a small piece of granulation tissue which was submittcd to the microscope and showed beautiful giant cells. He suggested that myeloid sarcoma and osteitis fibrosa were variations of the same condition; that in onc case we find very little growth, and call the condition osteitis fibrosa; in the other there is more rapid growth, and we call it myeloid sarcoma. The following cases have been described.

A woman, age 25 , had a cyst in the shaft of the ulna, there being swelling of ten months' duration. and no history of any injury. The cyst contained reddish fluid, and possessed a lining membrane of fibrous tissue, well formed externally, more cellular internally. The cyst was curetted and healed. (Ponzro.) 


\section{FIBROCYSTIC DISEASE OF THE BONES}

A girl, age 18, had a cyst in the shaft of the ulna ; there had been swelling since. childhood, but pain had only arisen three weeks before. The cavity was opened; it contained a thin straw-coloured fluid which could not be cultivated. A cyst wall of reddish soft tissue could be peeled from the cavity, which it lined; it consisted of granulution and myxomatous tissue, no trace of cartilage being visible. The cavity was packed, and an uneventful. recovery resulted. The radiograph reproduced in Jones's paper shows a central cavity with considerable sclerosis of the surrounding bone and some thickening of the shaft. The appearances are rather suggestive of a central abscess. (Robert Jones.)

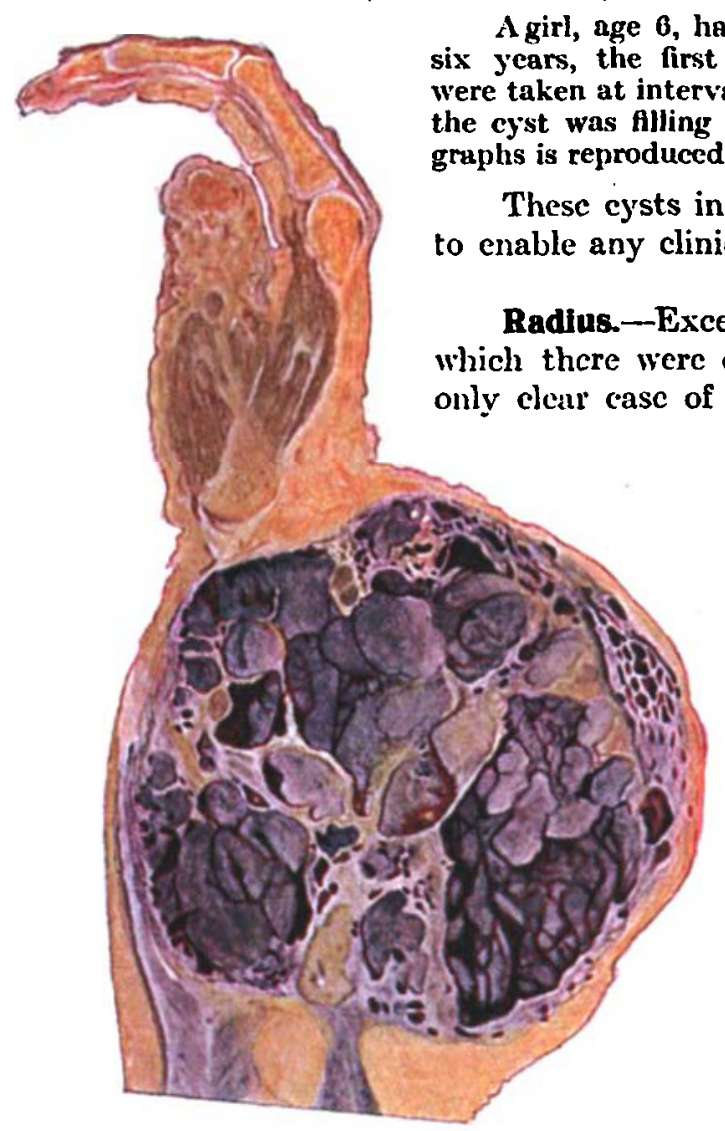

Fia. 34.-Cystic myeloma of lower end of radius. (Royal College of Surgcon' Museum. specimen 1(1378.) vecula being usual. Fig. 34, from a spccimen in the museum of the Royal College of Surgeons, shows a renarkable form of myeloma, which well exhibits the possibility of cyst formation in these tumours. The catalogue description is as follows.

"1637b. A vertical section of the lower part of the forearm with the hand. Expanding the lower end of the radius is a large circumscribed tumour, which consists of a congeries of variably-sized cysts, and measures about four inches in diameter. The contents of the cysts have been coagulated by the formol used in the preservation of 
the specimen, and appear to have been of a serous kind; into many of the cysts hæmorrhages have taken place. The tumour is in places surrounded with a thin shell of bone representing the remains of the radius. The solid tissue between the cysts near the surface of the growth shows the typical structure of a giant-celled sarcoma.

"The parts were removed from a woman, age 37 , admitted to St. Thomas's Hospital, under the care of Mr. Pitts, in March, 1900. She had sustained a Colles's fracture four years previously, and from that time the swelling had dated. The skin over the tumour was of a dusky hue, and had given way at one point. No loss of flesh had been noticed. The patient was discharged well in May."

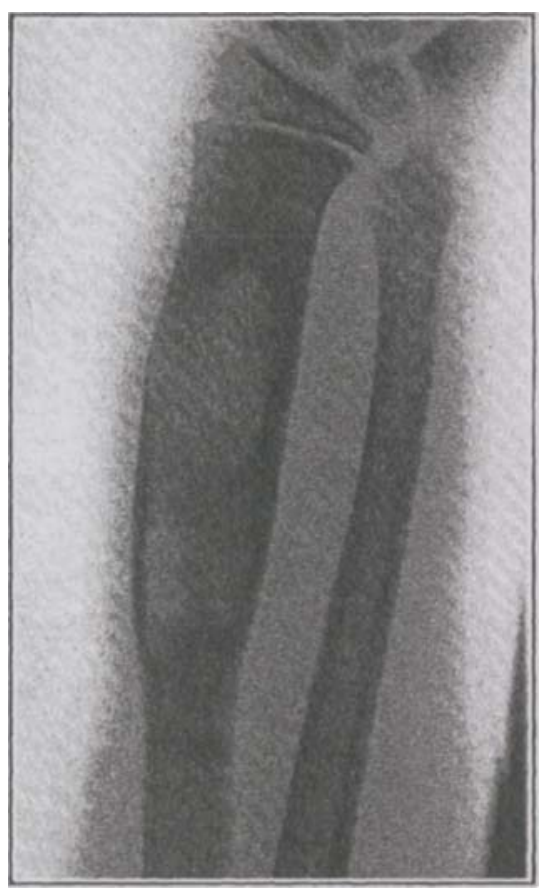

Fig. 3h.-Chronic abscess of radius.

Fig. 35, a radiograph of a chronic abscess of the shaft of the radius, shows the eccentric expansion of the bone and the slight sclerosis around the cavity. On account of the complete absence of periosteal thickening, there was great difficulty in diagnosing this condition from a sinple cyst.

Femur.-A larger number of cases of cysts, or of osteitis fibrosa, in the femur have bcen recorded than in any other bone. These cases, however, do not form nenrly so clear or so well-defined a group as do those in which the humerus is affected. The clinical picture is more complex, there is often a large solid tumour, and in a larger proportion of the cases there has been an associated affection of one or more other bones. Only those cases in which a single bone has been affected will be dealt with here, the inultiple lesions being reserved until a later section.

In a small number of cases there las been a cyst with little or no solid pathological tissue around, so that these closely resembled the usual form of cyst as it occurs in the humerus. The following case, reported by Mr. Maynard Heath, is perhaps the best example of this.

A boy, age 6, fell and hurt his left hip a year previously. Three months later he fell again, and broke the neck of the femur. He was treated in plaster of Paris, but never walked well. Upon admission to the Hospital, there was evident deformity and swelling of the upper part of the left thigh. The limb was shortened and everted, and crepitus could be obtained. A radiograph showed a globular enlargement involving the neck of the femur and trochanteric region, with a fracture through the lower part of the neck.

The bone was cut through bclow the cyst, and the upper part of the femur resected. The upper end of the shaft was fixed into the acetabulum by wiring. At the present time the boy has a good strong useful limb, with about three inches shortening.

The specimen is in the Museum of University College Hospital (237b), and is represented in Fig. 36. It shows a crst which occupies the base of the neck, and 


\section{FIBROCYSTIC DISEASE OF THE BONES}

about 2 in. of the upper part of the shaft, of the femur. The bone is a little expanded, the surface smooth, and the periosteum normal. Upon section, the cavity was found to be filled with soft, dark red, gelatinous masses, divided by several narrow septa. Bounding the cavity inferiorly was a semi-transparent stratum containing spicules of bone. The upper part was bounded by soft bone. The shaft of the femur at the point of section appears normal.

Nicroscopically, the red gelatinous material consisted of a finely granular structureless material, staining with eosin, and broken up by coagula of blood and fibrin. Surrounding this was a layer of dense fibrous cellular tissue, well supplied with vessels. The bone trabeculic are greatly reduced in thickness, and show absorption by osteoclasts. The marrow spaces are large, and contain a young flbrous tissue, which in places resembles myxomatous tissue. No cartilage was seen, and no collections of osteoclasts except in proxinity to the bone.

Silver has described a similar ease.

The patient was a boy, age 4 . Eighteen months before he came under observation he had injured his left hip, and had limped for a short time. Six weeks before, the limp reappeared. A radiograph showed a cyst involving the neck and upper inch of the shaft of the femur, with a fracture in the lower border of the neck of the bone. The cyst was incised through the trochanter, and a single cavity was found with smooth walls and no lining membrane. It was curetted ; the fluid was " serous," and proved stcrile on culture; no solid matter was removed. A flap of tissue was turned into the opening in the bone, and the wound closed. Six months later the limp returned; but as a radiograph showed a satisfactory increase in the density of the bone, nothing further was done. However, as the symptons persisted, and a later radiograph showed, if anything, an extension of the cyst, a further operation was performed a year and nine months after the first. 'The cyst was again opened, and was now found to have a dis-

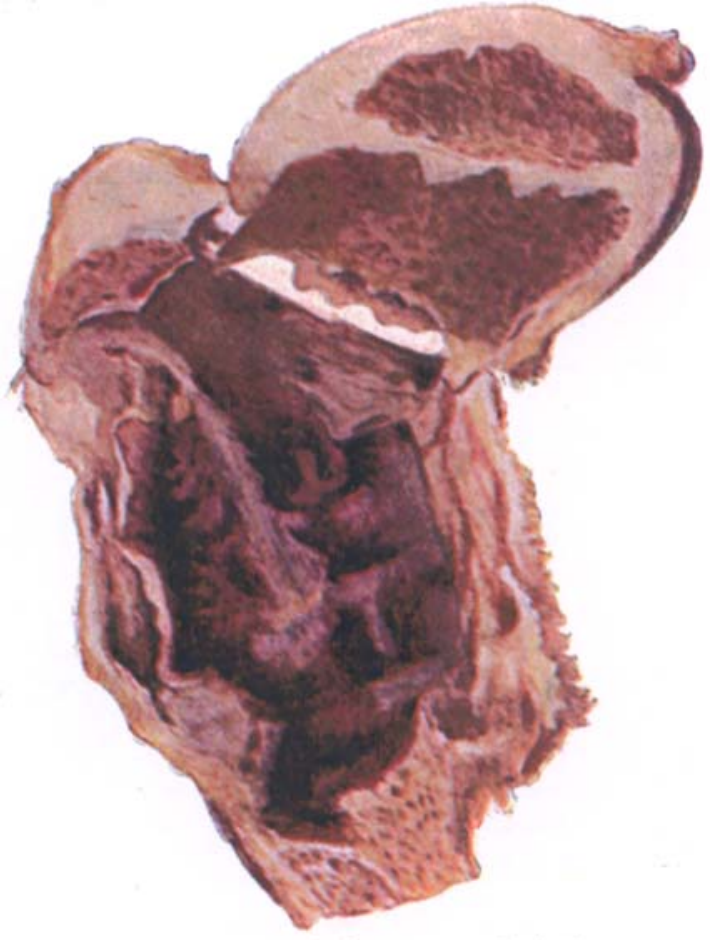

Fia, 36.-Cyst of the upper end of the femur. (Alaynard Heath's C'ase.)

tinct lining membrane. It was curetted thoroughly, the wall crushed in over a considerable area, and filled with bismuth paste. Silver says that a year after the second operation there was every indication that a cure had been accomplished.

l'athological examination of the wall of the cyst remored at the second operation showed that the bone trabecule of the cortex were separated by a fibro-granulomatous tissue consisting of long and short spindle cells, forming a network which was infiltrated here and there with round cells and with hamorrhages. A few newly-formed cenpillaries were seen. The Haversian canals were filled with a similar tissue. The bone trabeculix were lined with one or more layers of osteoblasts, and in some places there wcre groups of osteoclasts. The material obtained by curetting consisted of a fibroyranulomatous tissue, fibrinous masses which were infiltrated with round cells, polynuclear leucocytes, small and large hrmorrhages, some bone spicules, and irregular masses of cartilage; the bone spicules were covered with osteoblasts. 


\section{THE BRITISH JOURNAL OF SURGERY}

Simmons has reported another case.

A boy, age 5, had fractured the femur eight weeks before. The cyst occupied the neck and upper inch of the shaft of the femur. It was curetted, with a result which was described over three years later as perfect. The wall of the cyst showed small bone trabeculæ in a connective-tissue matrix, which in places was myxomatous, and in other places assumed the characters of normal medulla. Along the edges of the trabecula were many osteoblasts. In one section were a few giant cells. A few islands of cartilage were found in sections cut at the time of the operation.

It will be noted that these three cases, in which the clinical and pathological pictures were closely similar to those seen in the cysts of the upper end of the humerus, all occurred in young children. Another case described by Borchard,

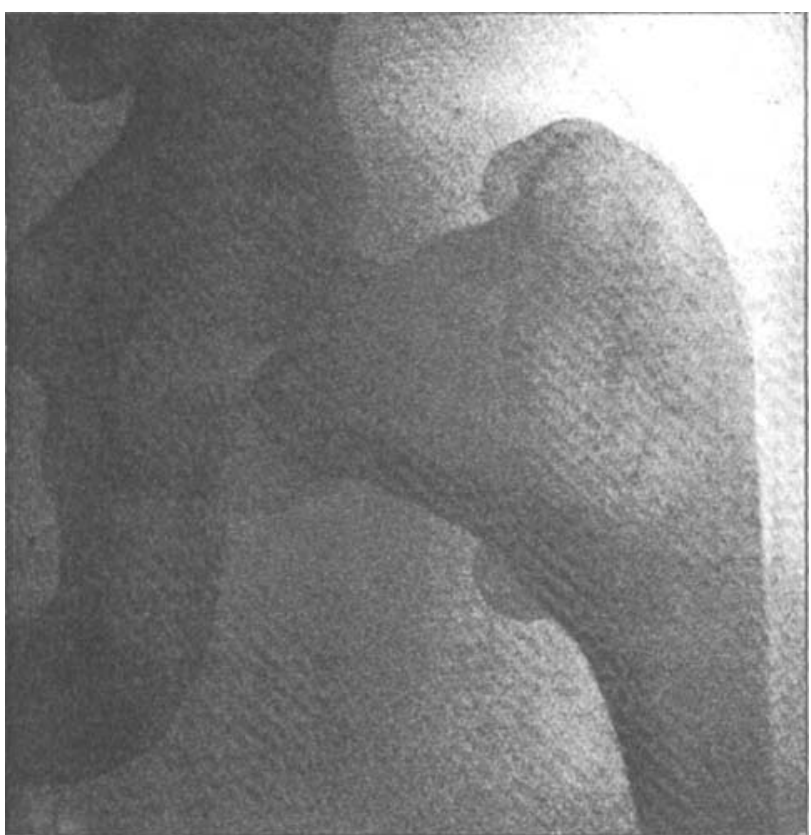

Fia. 37.-R. F. Cyst in the neck of the femur. of a cyst in the trochanteric region, in a boy, age 7 , diagnosed as a cyst resulting from the breaking down of a sarcoma, and cured by curetting, was almost certainly of the same nature. The only simple cyst in this region in an older subject. of which I have been able to find a record is one in a boy, aged 18 , mentioned very briefly by H. L. Taylor at the discussion upon Silver's paper. The details given are too meagre to enable this case to be classified. Bloodgood also reports a cyst in the trochanteric region in an old patient, age 70 , who suffered from osteoarthritis, and mentions a similar case of Braun's in a woman, age 78 .

It is far more common, in the upper part of the femur, to find that the cyst or cysts constitute only a minor feature, there being a mass of solid tissue, chicfly fibrous, in which they are embedded. The following case is, in most respects, typical of this class.

R. F., a healthy-looking girl, was weil until the age of 14 ; when she had slight pain in the right thigh, and began to limp. She attended St. Bartholomew's Hospital soon after. At that time the right femur was about $1 \frac{1}{2}$ in. shorter than the left, and was slightly bowed, convex antero-externally, at the junction of the upper and middle thirds. A radiograph showed that the shaft of the bone was slightly thickened at this point, and that on the outer side was a small raised point at which the cortical part of the bone was destroyed, as if a cloaca existed.

She continued to walk lame, the pain at times being severe. She was taken into the Hospital, but no exact diagnosis was made. In October, 1913, at the age 


\section{FIBROCYSTIC DISEASE OF THE BONES}

of 18, she returned to the Hospital, after an absence of two years. The pain was now severe, the femur was evidently bowed, and was 21 in. short. A radiograpin showed the same appearances in the shaft, but, in addition, the neck of the femur was examined, and showed the presence of a large cyst (Fig. 37). This, together with the fact that in the meantime my attention had been called to the condition of osteitis fibrosa, enabled me now to diagnose the condition.

A more careful examination of the radiograph of the shaft of the femur showed that it was larger than that of the opposite side for two thirds of the way down the shaft and that this upper part failed to show a clear thick cortex as on the other side. It was therefore thought that probably the disease extended down the shaft of the bone, for about two thirds of its length, to a point where an appearance of normal cortex reappeared (Fig. 88). The Wassermann reaction was negative.

In January, 1914, the cyst in the neck of the femur was explored from the front. It was found to contain a yellow fluid, and to be!lined with a thick flbrous membrane. The latter was removed, and the cyst curetted. Some fragments of cancellous bone were then removed from the interior of the head of the tibia and inserted into the cavity in the femoral neck, the wound being closed, except that a packing of gauze was left down to the aperture in the bone for forty-eight hours. Three weeks later the shaft of the femur was opened from the outer side; the cortex was thin, and the interior of the bone contained a mass of firm tissue, which was removed with the spoon and with a chisel; it completely replaced the inarrow. After its removal a cavity remained, surrounded by a thin layer of compact bone, and extending for a distance of more than 6 in. up and down the shaft, communicating below with the medullary cavity, but apparently still bounded above by diseased tissue. There was considerable hæmorrhage during this operation ; it was, however, easily controlled by packing. The wourd was packed and closed, the packing being removed after forty-eight hours. Good healing followed. The patient was discharged from the Hospital wearing a Thomas's splint. It is too early at the present time to record the result of this treatment.

Microscopic examination of the membrane which lined the cyst showed only fibrous tissue, which was for the most part rather loose in texture and vascular. There were only small

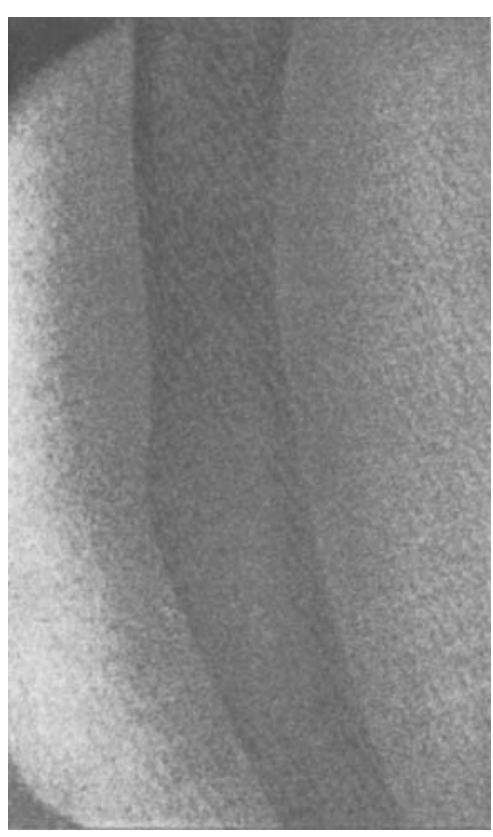

Fic. 38.-R. F. Shaft of femur filled with firm flbrous tissue. spicules of bone in the peripheral part. and no cartilage or giant cells were to be seen. The tissue from the shaft of the femur consisted chiefly of a firm fibrous or fibrocartilaginous tissue, in which were embedded spicules of bone; the latter were scattered throughout the mass, and were not confined to those parts which lay in the region near the cortex ; they must, therefore, have represented a new formation of bone. But there were practically no indications of active changes in the shape of deposit or absorption of bone. No osteoclasts were to be seen (Figs. 39 and 40). There were no cysts in the shaft of the femur.

In this case there was no definite history of a fracture, although the appearances in the radiograph suggest that the neck of the femur had given way at some time. There are many similar cases on record, in most of which a fracture occurred. The following may be cited as examples. 
In a woman, age 29 , there had been a fracture of the femur at 11, after which there was a gradual onset of pain, swelling, and deformity. At 29, after a slip, the

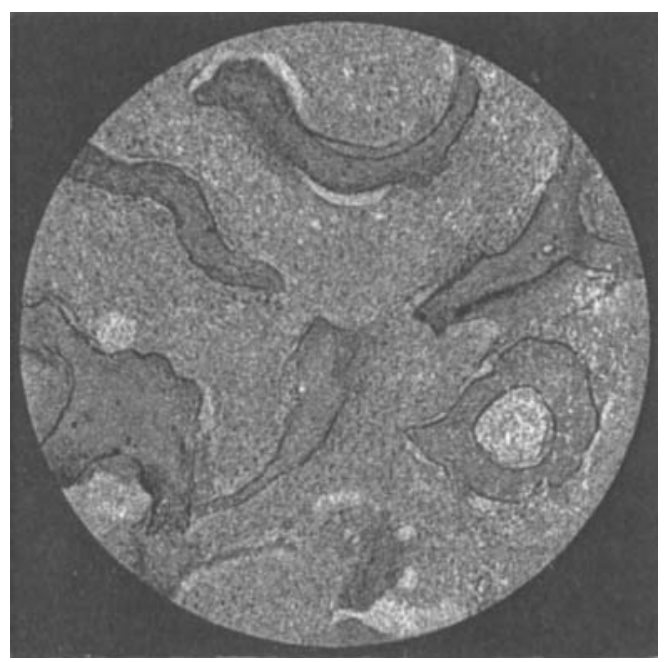

Fic. 39.-Tresue from Sham of Femur.

R. F. Spicules of bono in a frm fibrous marrow. No osteoclasts, and few osteoblasts. Specimen is not decalcified. (Low power.)

ground substance in the neck of the resembled fibrocartilage; in its meshes were pieces of bone and marrow. (KörTE.)

A woman, age 40, was a chronic invalid. She had süffered from scoliosis trom childhood. At $\mathbf{4 0}$ she fractured the right femur by a fall; before this she had suffered for some months from pains in the limbs, and for five months had been unable to walk. A fortnight after the first fracture there occurred a spontaneous fracture of the left femur. No operation was performed, but the patient died a short time after.

Post mortem, cysts were found in the upper part of the shafts of both femora; in the right femur there were three such cysts, in the left there was one large loculated cyst. These cysts were lined with firm tissue, in places fibrous, in places fibracartilaginous. Körte believed these cysts to have arisen by the degeneration of enchondrolimb became useless. At that time there was much -deformity of the upper end of the femur, rendering the limb $11 \mathrm{~cm}$. short. The femur was explored, and in doing a wedgeshaped osteotomy the osteotome entered a cyst. Union did not take place, and a year after the first operation an amputation through the hip-joint was carried out. The patient died of shock. A pseudarthrosis was found at the site of the osteotomy, the ends of the bone being flattened and united by fibrous tissue. Below this there was no abnormality, but above there was a large cyst. Above the cyst, the head, neck, and upper part of the shaft of the femur were filled with a firm white tissue, in which was a second cyst. The cyst had a bony wall 2 to $5 \mathrm{~cm}$. thick; inside this was a firm layer of cartilaginous consistency, which could be peeled off with difficulty.

Microscopically, the cyst walls consisted of fibrocartilage; the the femur :was firm fibrous tissue, which much

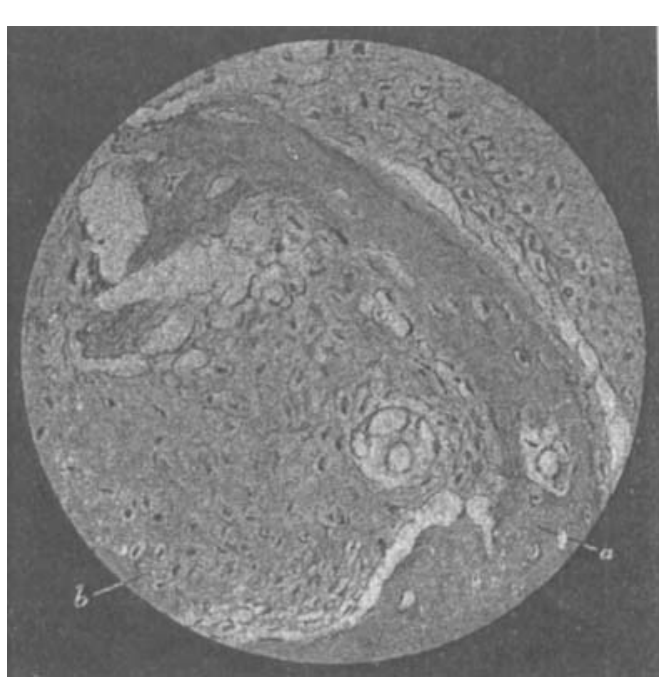

Fio. 40.-Thgof From Shart of Fruror.

R.'F. (a) Bone with surrounding fbro-cartilage; (b) Fibro-cartilage. (High power.) mata in each case, in this following Virchow's hypothesis. (KörTE.)

In a girl, age 14, bending of the femur commenced at the age of 6 . At 14 the 


\section{FIBROCYSTIC DISEASE OF THE BONES}

femur was much bent, 4 to $5 \mathrm{~cm}$. short, enlarged, and painful on pressure. The centre of the deformity lay a hand's breadth below the great trochanter. An exploratory operation revealed a cyst the size of a pigeon's egg, and above this several smaller cysts ; these.were all embedded in a firm fibrous tissue of cartilaginous consistency. The whole of this diseased tissue was scraped out, and the bone fractured. and put straight. It united well, and six years later the limb was strong and useful, although short. The walls of the cyst. consisted of an avascular connective tissue : above this the tissue was very various, containing fibrous tissue, fibrocartilage, and bone. (Schlange.)

A girl, age 18, had fractured her femur at 18 ; the fracture united, but some months later the bone became painful and began to bend. At 18 there was an angle in the femur, and the limb was $2 \mathrm{~cm}$. short. The femur was explored, and found to be filled with a yellow tumour containing a cyst at the site of the fracture. The diseased tissue extended up into the great trochanter and $4 \mathrm{~cm}$. down the shaft. This was all removed, the bone being cut through and straightened. Two years later the limb was a little short, but strong and useful. In this case the tissue removed was much more cellular, and contained patches of bone. It was very rich in giant cells, especially in the regions of softening; so much so that if the general character of the tumour had not been known, one might, from examining these parts, have taken it for a myeloid sarcoma. (Schrange.)

A boy, age 7, had fractured his femur at the age of 3. After the fracture there had been a gradual onset of painless bending of the bone, the point of bending being a little below the trochanter. A cyst was opened, and firm yellow tissue found extending up and down the femur. This was scraped out, and the femur fractured and straightened. There was good union in eight weeks. The wall of the cyst consisted of fibrous tissue; the other tissue showed fibrocartilage. (Schlange.)

A girl, age 17, had fractured her femur twice at the age of 5. Death from ether pneumonia followed an exploratory operation, so that the specimen was obtained for examination. It presented a most complex picture, there being cysts, flbrous. tissue, patches of bone, and large masses of cartilage. The appearances were very similar to those in the femur in von Recklinghausen's case of multiple lesions (Fig. 55'. (KüstER.)

A boy, age 15, with a previous fracture at 5 , was a case very similar to thosealready described; this also gave a good result after scraping out the diseased tissue. (Koch.)

In a man, age 37 , the first symptom was pain at 86 . A cyst was diagnosed in the femur just below the trochanter, and this was opened and curetted, with a good immediate result. Two and a half years later, however, there was severe pain, and the femur was found to be deformed. There was then thickening of the whole of the tipper end of the bone, bending of the femoral neck, and the radiograph showed the cyst still present. In this case, thought at the time of the operation to be a simple cyst, there was doubtless also a diffuse change in the surrounding bone, this diseased tissue not being completely removed. (Brade.)

Other similar cases have been described by Kehr, Glimm, Halsted, Kammerer, and others. Borchard also described such a case as a spindle-celled sarcoma. As he treated it by scraping out the diseased tissue, and there was a good result a year later, it may be assumed that the diagnosis was incorrect.

The following case is described by Roughton.

A girl, age 13, had fractured her femur, by slight violence, immediately below the great trochanter. The diagnosis of sarcoma was made, and the limb amputated through the hip-joint. In the specimen removed (Fig. 41), which is preserved in the museum of the Royal Free Hospital, there is a cyst of considerable size, with bony walls, and a smooth lining; the contents consisted of gelatinous tissue and blood-clot. The periosteum was thickened and gelatinous, and the muscles around infiltrated. The gelatinous tissue, both in and around the cyst, consisted of spindle 
and stellate cells, in places myxomatous. Externally these actually inflitrated among the muscle fibres, so much so as to raise strong suspicion that they were sarcomatous. Roughton, however, thought that this was a case of a simple cyst; and this is confirmed by the fact that the patient is alive and well at the present time, five and a half years after the amputation.

In the following case the diagnosis rests upon clinical grounds, no operation having been perforned.

E. B., a woman, whose exact age was doubtful, in 1880 , at the age of 15 (?), was admitted at St. Bartholomew's Hospital, with the history that two years before, she had fallen and injured her right thigh; she was able to get up and walk home, but the pain continued for some weeks. Ten days before admission she again injured the hip; since then there had been much pain, and a swelling had appeared.

A hard swelling was found in the upper part of the right femur, as if the bone was thickened by about 1 in. It was slightly painful, but hip movenents were free. A diagnosis of chronic periostitis of the fenur was made.

Two years and four months later she was readmitted, her age being now given as 16. Six months before, she noticed that the right thigh was bent. There was then a sudden bowing outwards in the right femur about 8 in. to 4 in. below the great trochanter, the bone being thickened at the bend; the tissues around were hot and slightly tender. The right thigh was 17 in. shorter than the left : the whole limb was, however, 23 in. short (this probably alluded to the total apparent shortening). Under ether, Mr. Smith, by the exercise of slight force, fractured the femur; he thought that there was disease at the point of curvature. A long splint was applied; the shortening was then $\$$ in. On returning from the convalescent home, four months later, the girl walked without crutches, but with a slight limp; there was not more bowing, but the bone was more thickened at the bend; the shortening was now 1 in.

The patient was next seen by me at the Metropolitan Hospital on July 7,1907 , twenty-nine years from the time of the first injury; she came for the provision of a high boot, but walked with crutches and put very little weight upon the limb. The shortening was now $3 \frac{1}{2}$ in.; the femur was much thickened in its upper part and bowed outwards. There was fixed adduction at the hip-joint, but, except for this, the movements at this joint were free. A skiagram (Fig. 42) showed that the neck, trochanters, and upper 3 in. of the shaft of the femur were expanded, rarcfied, and curved; the cxpanded area was subdivided cxtensively by trabecula. The lower limit of the discased area was sharply marked off from the rest of the shaft. The history given was so inaccurnte as to lead to the supposition that the condition had arisen quite recently; a diagnosis of endosteal sarcoma was made, and amputation advised. This was refused, and the patient lost sight of for eighteen months. She then returned, and the condition was found to be absolutely unaltered. Having in the meantime seen a patient with fibrous osteitis, I was now able to make this diagnosis, and I advised the correction of the deformity by the removal of a wedge. This was, however, refused. Since that time the patient has been under observation from time to time, and the condition has not altered in any respect. The Wassermann reaction is negative. 


\section{FIBROCYSTIC DISEASE OF THE BONES}

The specimens from Heath's and Roughton's cases, already mentioned, are the only two which I am able to find in London museums, illustrating cysts in the femur.

From the cases described above, it is much more difficult to establish a definite clinical picture than it is in the case of the humerus.

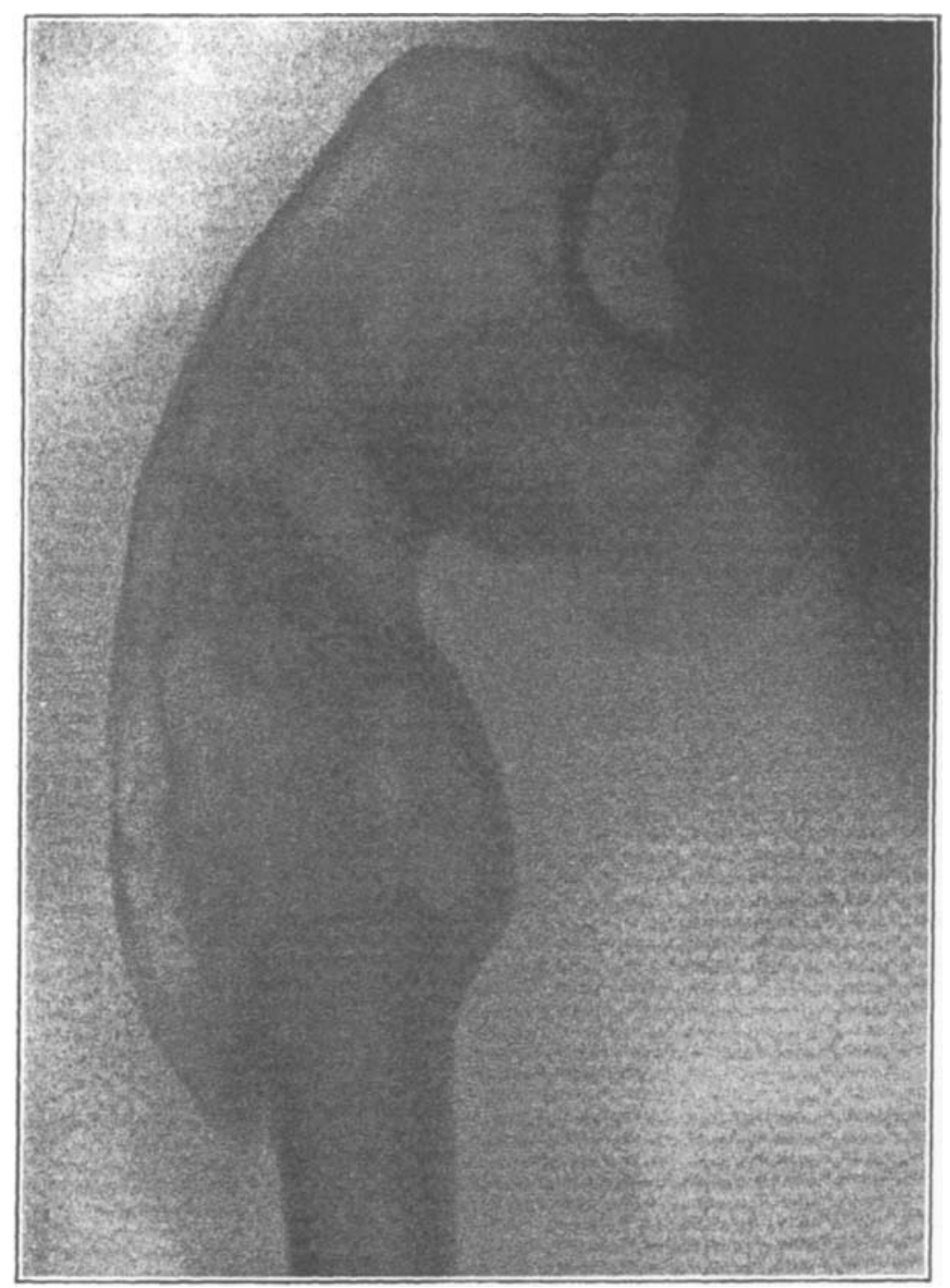

Fro. 42.-E. B. Fibrouystio diseaso of the upper end of the fonur.

Clinical History.-Here again fracture is very common, and the fracture appears, sometimes at least, to have been incomplete. In Silver's case, and in my first case, there appear to have been fractures which took place without the patient's knowledge. As a rule, union of the fracture has been good, but 
there has often been subsequent bending and swelling. It almost appears as if the fracture results in an increase in the formation of new fibrous or fibrocartilaginous tissue, with resulting enlargement and bending of the bone.

There appears to be a much wider age distribution than in the case of the humcrus. Whilst the simple cysts have occurred in young children, the formation of masses of fibrous and other tissue may apparently go on at any age. Some investigators have suggested that the real onset of the disease has been earlier than at first appears, the patient's attention only being called to the condition when considerable deformity, or else a fracture, occurred. This is rendered probable by the long histories obtained in some of the cases. But whether the disease can arise for the first time in adult life or not, it is clear that it can progress at any age; Brade's case makes this quite certain.

Radiography.-The diagnosis must depend upon the radiographic appearances. When there is considerable expansion of the bone with the formation of cysts, these are very characteristic. Fig. 42 will serve as a good example. It may be taken as a rule that there always remains a shell of cortical bone around the tumour except at the site of a fracture. The complete disappearance of the cortex at any point should at once raise suspicion that a sarcoma has to be dealt with. The central position of the tumour is important, and also the absence of periosteal thickening and of sclerosis of the surrounding bone.

The chief difficulty will arise in cases in which there is little expansion of the bone. In Fig. 38, from my first case, the only change shown is the uniform density of the bone of the shaft of the femur, and the difficulty in getting any indication of a clear cortex of compact bone. The diagnosis was only made in this case by the discovery of the cyst in the femoral neck.

An apparent subdivision of the translucent area by trabeculæ is much more frequent in the femur than in the humerus.

Differential Diagnosis.-Two points only need be mentioned. In the first place, a fracture through a diseased area may be looked upon as a simple traunatic fracture unless carefully examined in a radiograph. In the second place, there is a very real difficulty in diagnosis from sarcoma. In the latter connection, the length of the clinical history is of most importance, and the points already mentioned in the radiography-viz., the central position, the persistence of a layer of cortex, and the absence of periosteal changes-will assist.

Mr. Raymond Johnson has sent ne notes of the following case in which this difficulty arose.

- A man, age 23, fractured the middle of the shaft of the femur in June, 1911. The injury was slight, but there were no previous symptoms. Union occurred with some deformity. No radiograph was taken. He returned to work as a porter until July of the following year, when he was re-admitted to the Hospital with pain at the seat of the fracture, which was relieved by a short period of rest. He returned to work until the following October. He then fell over a box and the pain returned. A splint was applied, but without relief. In April, 1918, there was considerable swelling at the site of the fracture, crackling could be obtained upon pressure, and there was a sense of fluctuation; the shortening was 2 ins., as before. On April 21, whilst standing, the bone "cracked," and the pain became more marked. A radiograph taken at this time showed what appeared to be a simple cyst. On April 23 an exploratory operation was performed. Two large cysts were opened; they possessed thick fibrous walls, and contained clear straw-coloured fluid. The 


\section{FIBROCYSTIC DISEASE OF THE BONES}

fractured ends of the expanded bone projected into the cysts. The cyst wall was freely removed and the remains of the bony wall crushed together. The wound was closed and a splint applied. Slight suppuration ensued, and healing was slow, but the patient left the Hospital in July. The limb remained very weak, and walking was only possible with crutches. He was re-admitted in October, 1913. There was now $3 \mathrm{in}$. of shortening; also marked swelling of the femur, and fluctuation was obtained. Union of the fracture was doubtful. The radiograph now showed the cyst with part of the cortical wall missing, but this might have been due to the previous operation. On Nov. 15 an operation was commenced with the object of completely removing the affected part and putting in a graft. It was found, however, that around the cyst a solid white growth was infiltrating the muscles. The wound was closed. Microscopic examination showing that the tumour was a spindle-celled sarcoma with some giant cells ; amputation was performed a week later

This is a very unusual case. If the tumour was sarcomatous from the first, the history was an unusually long one. It may be suggested that possibly there was a sarcomatous change in the tissue of a pre-existing innocent cyst. Such a change in an undoubted case of osteitis fibrosa occurred in Lawford Knagg's case (see later).

A specimen from another case of sarcomatous cyst of the femur is in the Museum of the Royal Free Hospital (I. 78.)

The patient was a girl, age 15 , who fractured her femur, about the middle, by slight yiolence. The limb was fixed.upon a splint, but a radiograph showing that the fracture had occurred through a pyriform swelling of the bone, amputation was performed. The bone contained a central cyst, filled with blood-stained serous fluid, and possessing a lining membrane. There was no periosteal growth, and at first there appears to have been some doubt whether the tumour was really a sarcoma. The section, which shows spindle and other cells of varying size and irregular appearance, with patches of irregular and imperfectly-formed bone, seems, however, to settle the question in the affirmative.

In the museum of the London Hospital there is a specimen of a mycloid sarcoma expanding the inner side of the shaft of the femur just below the middle. The cavity is not quite central, but is formed rather by an expansion of the cortical part of the bone; it communicates with the medullary cavity by a large aperture. It was removed from a girl, age 12, it was of nine months' duration, and was said to have followed an injury (697b.). Specimen 4422 in the museum of Guy's Hospital is a very similar tumour; it also is described as a myeloid sarcoma

Two other recorded cases, as follows, are of interest in the diagnosis.

In the discussion upon Silver's paper, Mckenzie referred to a central chondroma of the femur, situated immediately below the trochanter, which he had removed from a girl, age 14. There had been lameness since the age of 7 . The femur was acutely bent at the site of the tumour. The tumour was shelled out with ease, a very distinet bony wall being left. The latter was cut through, and the deformity corrected. A good result ensued. (McKenzie.)

The other case was one of echinococcus cyst involving the trochanters and greater part of the shaft of the femur in a man, age 33. There had been pain for fourteen years, but there was no deformity. The radiograph showed distention of the femur by a very translucent cyst. Upon exploration, echinococcus cysts at once escaped. It appears that a diagnosis of this case from a simple cyst would not ibe possible without exploration. (RITrER.)

Pathology. - There appear to be two detinite types among these conditions as found in the upper part of the femur. The first, the simple cyst, occurs in 
young children; closely resembles the cysts of the upper part of the humerus, both clinically and pathologically; and shows in its wall fibrous tissue of various degrees of organization, cartilage, bone showing absorption and deposit, and hæmorrhages.

The second occurs at all ages ; pathologically, it presents rather a mass of new growth containing one or more eysts than a simple cyst. But there is some evidence that in the early stages the cyst is the more important part, the growth extending later. The solid mass may exhibit cartilage, either hyaline or fibrous ; spicules of bone, showing deposit by osteoblasts and absorption by osteoclasts; fibrous tissue of all sorts, from fully-formed dense fibrous tissue to spindle-celled vascular young tissue, or even granulation tissue; in places there has been myxomatous degeneration. The whole pathological picture, therefore, is very complex.

The Lower End of the Femur.-Cysts in the lower part of the femur are comparatively rare, and do not form a very well-defined group. In the following case, for notes of which $I$ am indebted to Dr. Pennefather, there was a simple cyst.

B. D., a woman, age 34, gave the following history. Eighteen years ago she fractured her left femur just below the middle of the shaft; the fracture occurred without any violence, merely as the patient turned round whilst standing; she was in bed for six weeks, and at the end of thrce months the leg was quite strong. Four years ago she fractured the same femur at the same spot, again whilst turning; she was in bed for six weeks, and the leg has always seemed weak since, and has ached, but not caused any pain. The leg set badly, and there has always since been an angle, convex forwards and outwards, at the site of the fracture. On Oct. 3, 1913, a third spontaneous fracture occurred at the same site. As no union had taken place by the end of November, a radiograph was taken; this disclosed the fact that the fracture had taken place through the upper end of a cystic expansion which extended down to the lower end of the shaft of the femur. On December 3 the ends of the bone were refreshed by Mr. R. C. Bailey and wired together, and the cyst was opened and thoroughly curetted; it contained clear fluid and no solid material. At the present time (May. 1913) union is present, but the limb is not strong enough to bear the patient's weight.

Pfeiffer recorded four cases of cysts of the lower part of the femur.

The first was in a boy, age $2 \frac{1}{2}$, in whom spontaneous fractures occurred, first of the lower end of the left femur, then, five months later, of the same part of the right fernur. - Six months after the second fracture he complained of pain and refused to stand; radiographs then showed that the lower half of the right femur was enlarged, and that there was a cyst at the lower end; in the left femur there was a fracture through a cyst quite at the lower end of the shaft. The left femur was. straighteried by operation, and consolidated well. Microscopic examination showed the changes of osteitis fibrosa, with a few free giant cells.

In a second case the cyst occupied $4 \mathrm{~cm}$. of the lower third of the shaft of the femur in a woman, age 41 : there had been pain for some months, and the patient had suffered from an inflammatory disease of the knee at the age of 17 . The cyst was explored, contained chocolate-coloured fluid, and was lined by a smooth wall, which again showed the changes of osteitis fibrosa, with no frec giant cells.

The third patient was also a woman, age 22 , in whom gradual swelling had followed an injury to the right knee nine months before. The cyst occupied the middle of the femur, and was multilocular. Its walls showed all the changes of ostcitis fibrosa, including cartilage-like tissue, and in some parts a nucleated fibrous tissue, with isolated giant cells and structureless calcified masses. 


\section{FIBROCYSTIC DISEASE OF THE BONES}

In the fourth case, a woman, age 20, there was a tumour of the lower part of the right femur, of three years' duration, which was enlarging. Tissue from it showed the structure of a giant-celled sarcoma, which at some spots had undergone mucoid degeneration. The bone from around the cyst showed typical osteitis fibrosa.

The first three of these cases agree with other cases described as simple cysts or as osteitis fibrosa. The last of them presents analogies with certain cysts of the tibia and fibula, which show the structure of myeloid sarcoma; these will be mentioned again.

Simmons describes the following case

He explored a cyst in the middle of the shaft of the femur in a woman aged 28 , through which a fracture had occurred. Good union resulted, and the limb was strong a year later. The tissue removed is described as;consisting of inflammatory fibrous tissue and granulation tissue.

In the following case, related to me by Dr. Michel, a cyst of the lower part of the shaft of the femur was diagnosed upon clinical and radiographic grounds.

A boy, age 10, fell from a swing (about one and a half metres) and fractured the femur near the lower end, He was admitted to the German Hospital, and treated on a Zuppinger double inclined plane. The radiograph was taken by Dr. Finzi, who had examined the three cases of cyst of the humerus related at the commencement of this paper; he at once diagnosed a simple cyst. No operation was performed; good union took place with abundant callus, but with some lateral displacement (Fig. 43).

McKenzie, in the discussion upon Silver's paper, reported a cyst in the outer condyle of the femur in a woman, age 40 .

Bloodgood relates two important cases of cyst in this region, as follows.

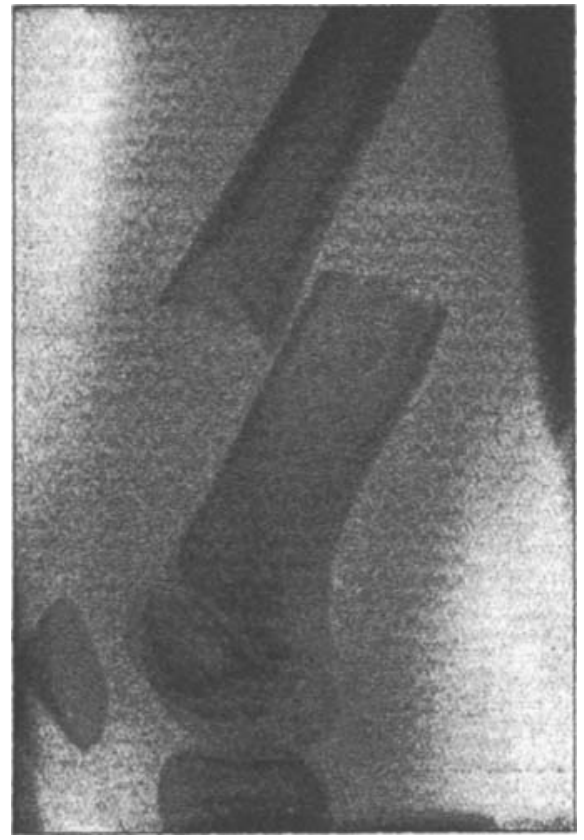

Fra. 43.-Dr. Michel's case of cyst of the lower end of the fenur.

In one, in a woman, age 32 , there was a very large cyst, which was watched for ten years; at the end of this time its size was enormous. It was then opened, curetted, and partially excised. The patient died of hæmorrhage. There was a thick outer wall of bone, the cyst was subdivided by septa. The tissue resembled osteitis fibrosa. Areas of cartilage were not found, but there were a few giant-cell areas, which could be seen as darker, somewhat pigmented ones. Bloodgood classes this case in a group in which the distended shell of bone is partitioned into cavities, some of which contain fluid, some solid contents.

The second case occurred in a woman, age 20 . It was watched until eleven years later, when it was of very great size, the bone being expanded very abruptly. Curetting was carried out, but amputation had to be performed on account of hamorrhage. There was a thick connective-tissue wall. Bloodgood classes this with two large cysts of the head of the tibia which were probably myelomata. 


\section{THE BRITISH JOURNAL OF SURGERY}

Meissner also reported a case of a large cyst in the lower end of the femur; I have been unable to see the original paper.

These cysts in the lower end of the femur seem to fall into two groups. On the one hand, there are the simple cysts, resembling those occurring in the upper part of the humerus ; on the other hand, there are the large cysts of the lower extremity of the bone, which present affinities rather with myelomata.

Tibia.-Several distinct types of fibrocystic disease are found in the tibia. Schlange reported the following two cases of cyst of the upper part of the bone.

In the first, pain and swelling commenced after an injury, at $12 \frac{1}{2}$; this became worse after a second injury nine months. later, but there was no fracture. The cyst occupied the upper two thirds of the shaft, and extended right up to the epiphyseal line. It was opened, and found to be smooth-walled, the wall being formed of a reddish-brown tissue; externally to this was rarefied bone without any evidence of growth. The fluid contained blood corpuscles. In the wall, except for pigment and scanty fat and giant cells, no

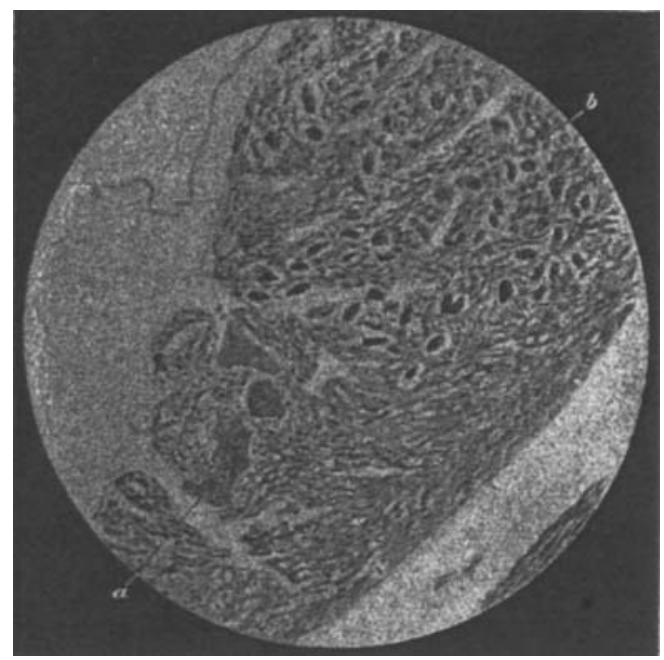

Fic. 44.-Wint. of Cyst. (Mr. Fairbank's Case.)

(a) Bone; (b) Spindle-celled tissue with numerous giant.-cells. (Low power.) formed elements were recognized. There was a good recovery.

The second patient was also a boy. There had been pain and swelling in the upper part of the tibia for a long time, but at the age of 12, after an injury, this became more marked. A cyst was found, extending from the upper epiphyseal line to the middle of the bone. It was opened, was found to be similar to that, found in the previous case, and was scraped out. It healed well and the patient made a good recovery. The fluid contained blood corpuscles and pigment. In the scanty fibrous tissue which formed the cyst wall and the septa, were nucleated fibrous tissue and patches of bone. There was no epithelial lining, and no sign of growth.

Beck described a similar case.

$A$ boy, age 10, suffered from pain and swelling after three successive

injuries to the tibia. There was no fracture. The cyst expanded the bone close to the upper epiphyseal line. It was opened and the contents cleared out, the walls being then partly crushed in. Good consolidation followed. Beck's second radiograph, taken two months after operation, shows a residual space, at a slightly greater distance from the epiphyseal line than in the first radiograph. Microscopic examination showed fragments of bone with many round cells, specially around the vessels. There was no epithelial lining and there were no bacteria. Beck thought that in this case, and in another of the lower end of the tibia, the accidents were important in the causation.

These cysts of the upper part of the tibia resemble, clinically and pathologically, those in the upper part of the humerus. The following case related to me by Mr. Fairbank was also similar.

The patient was a girl, age 7 , in whom a swelling of the middle of the shaft of 


\section{FIBROCYSTIC DISEASE OF THE BONES}

the tibia had been noticed for four or five weeks. A radiograph showed a clear expansion of the middle third of the shaft. This was opened, and found to be a cyst with a firm fibrous wall, which was removed. Three months later the patient was quite well. Microscopic examination of the wall showed some fragments of bone externally, next to this firm fibrous tissue, and internally a spindle-celled tissue in which were numerous osteoclasts ; this latter tissue resembled a myeloid sarcoma (Fig. 44).

Braun relates a similar case.

The patient was a girl, age 18, who had suffered from pain in the leg for four weeks, but in whom there had been a swelling of the tibia for some years. The cyst occupied the middle of the shaft of the tibia ; it was opened, a clear yellow fluid evacuated, and a soft lining membrane scraped out. Two smaller spaces were found, cut off from the large one by septa which were partly bony, partly membranous. The bone healed well. Cultures of the fluid yielded a white

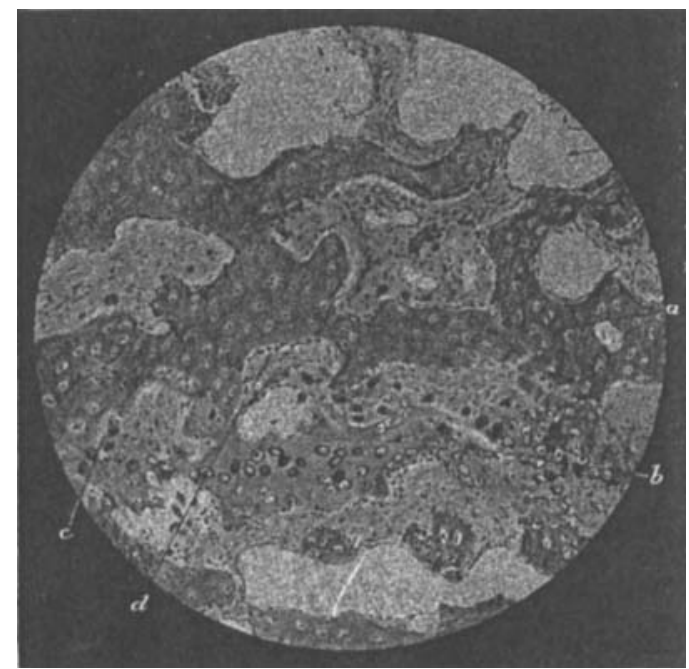

Fio. 45.-Contents or Cyst. (Jediard's Case.) (a) Well-formed fibrous tissue; (b) Spindle-celled tissue with gint cells. (Low pover.) staphylococcus which liquefied gelatin slowly and was avirulent to animals.

This is the only cyst, of which I have been able to find a record, from

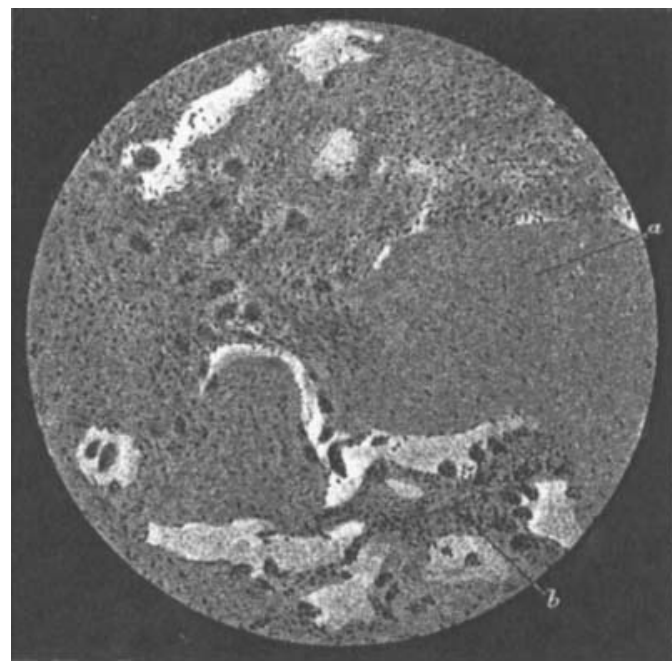

Fra. 46.-War. - of Cyst. (Lediard's Case.)

(a) Bono; (b) Cartilage : (c) Osteoclasts in Howship's lacuna; (d) Layer of osteoblasts. (Low power.) which an organism has been recovered; and in spite of the opinion of the author that the cyst was infected, it seems extremely probable that here the organism was the staphylococcus epidermidis albus. Braun's description of the microscopic appearances is not very clear.

Beck recorded the following case.

A cyst was found in the lower end of the tibia in a girl, age 12, pain and swelling following an injury at that age, but no fracture occurring. The cyst expanded the bone close to the lower epiphyseal line. It was opened and curetted. Recovery was complete in four and a half months, and the girl was quite well two years later. The cavity contained a black viscid substance; the walls were thick, and to their inner side was attached a stratum of greyish white material. This had the appearance of cartilage, and on section proved to be so.

VOL. II.-NO. 5 . 
Retzlaff, Fedden, Studeny and others also report simple cysts of the lower end of the tibia in young people.

These simple cysts of the tibia, whatever their situation, seem to form a well-defined group. They occur in young people; they have often arisen after injury or, at least, attention has been called to them by an injury; pain and swelling are the prominent symptoms; curetting has resulted in cure.

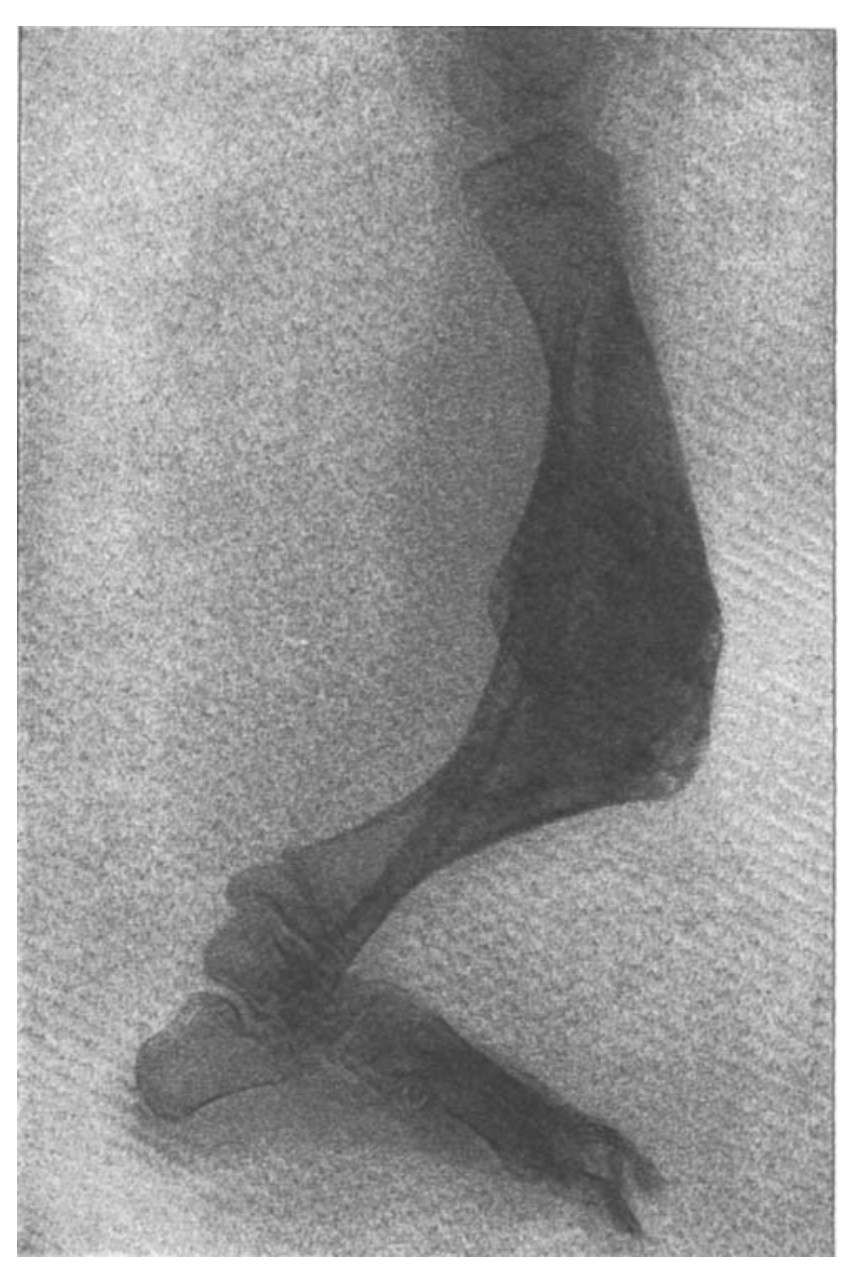

Fic. 47.-J. O. Radiograph of leg. (R. Jones's Case.)

The pathological descriptions are not very complete, no entirc specimens having been obtained for investigation; but, with the exception of Fairbank's case, the cysts appear to have been definitely simple, to have been lined with fibrous tissue with occasional patches of cartilage, and to have shown no evidence of growth. In Fairbank's case the internal part of the cyst wall closely resembled a myeloid sarcoma in structure.

An important case is described by Lediard, the specimen from which is in the museum of the Royal College of Surgeons (61/1913).

The patient was a girl, age 14; the swelling of the lower part of the tibia had been progressing for nine months and had recently become painful. It was explored, and found to be cystic, containing a clear watery fluid tinged with blood. The limb was amputated through

the knee-joint a few days later. The cyst was found to expand the bone in all directions; there was a very thin shell of bone around. The interior of the cyst was not quite smooth, there being several small bone septa, cutting off small loculi. The epiphyseal cartilage projected into the interior of the cyst, and at one part appeared to be eroded. Lediard described the cyst as an innocent one, and the processes found under the microscope as consisting of the rapid absorption of bone by phagocytic cells and osteoclasts. 


\section{FIBROCYSTIC DISEASE OF THE BONES}

Re-examination of the cyst and its contents, at the College of Surgeons, has, however, yielded some further facts. The contents of the cyst (Fig. 45) consist partly of clot, partly of organized tissue; the basis of the latter is a fibrous tissue, which in some places is well organized, in other places, however, shows a spindlecelled stroma. The latter is very vascular. Giant cells are numerous throughout, and these, lying in the spindle-celled stroma, with no bone in the neighbourhood, produce a tissue which it is difficult to differentiate from that of a myeloid sarcoma.' In the wall of the cyst (Fig. 46), the external part consists of well-formed bone, with large marrow spaces; both absorption of bone by osteoclasts and deposits by osteoblasts are evident; in some places there are masses of cartilage which lie in contact with the bone. Nearer the interior of the cavity, the spaces between the bone are filled with a very cellular spindle-celled tissue containing numerous giant cells. Further in still, this cellular tissue continues, but it is interrupted by strands of well-formed fibrous tissue, some containing numerous nuclei, some almost non-nucleated. The innermost layer of all consists of the same spindlecelled tissue with giant cells which is found in the interior of the cyst.

This specimen appears to be of grcat inportance. At the first examination, which was complete except that no sections were examined of the small masses of tissue which lay within the cyst, it appeared that the cyst was simple. A further examination shows, in places at least, the structure of a myeloma. The external part, however, examined by itself, might well have been diagnosed as a cyst in the condition usually described as osteitis fibrosa. Several questions are at once suggested: Are many other cysts really of the nature of myeloids? Are all endosteal myeloid tumours of the same sort, or are there different grades of malignancy?

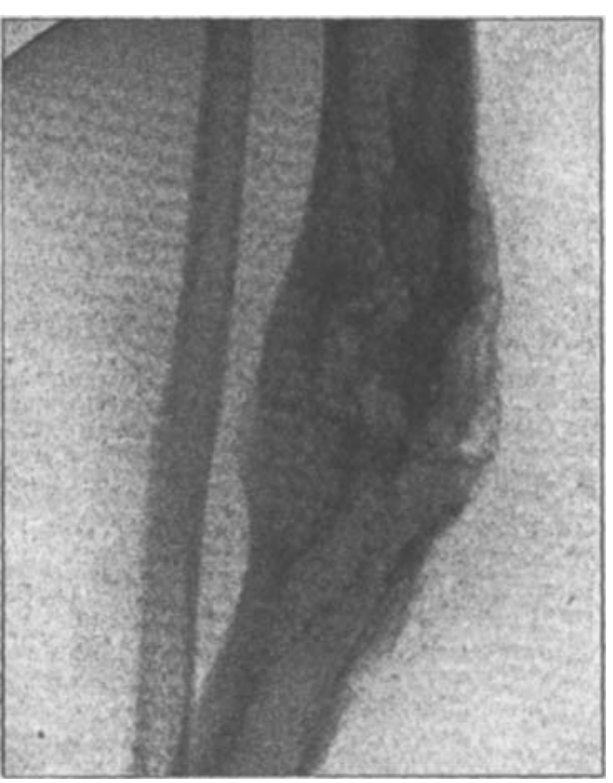

Fra. 43.-J. O. Radiograph of the tibia and fibula six years sfter operation. (R. Jones's Casc.)

May the changes usually described as osteitis fibrosa really represent only the reaction of the bone and marrow around. some other process, such as the formation of a myeloma?

Bloodgood refers to a specimen of Rosswell Park's in which there was enormous expansion of the head of the tibia by a cyst, Labert figured a similar specimen in his atlas, and another specimen of the same sort is in the Museum of Guy's Hospital (4430).

Brade reported another case.

In a man, age 24, there was an expansion of the head and neighbouring part of the shaft of the tibia of seven months' duration. 'This was curetted, and healed slowly. It proved, microscopically, to consist of a spindle-celled tissue with masses of giant cells.

The following quite different type of cyst in the tibia has been described by Glimm. 
In a man, age 25, a swelling appeared upon the tibia eighteen months after an injury. This was explored, and found to be a periosteal cyst-i.e., the cyst lay external.

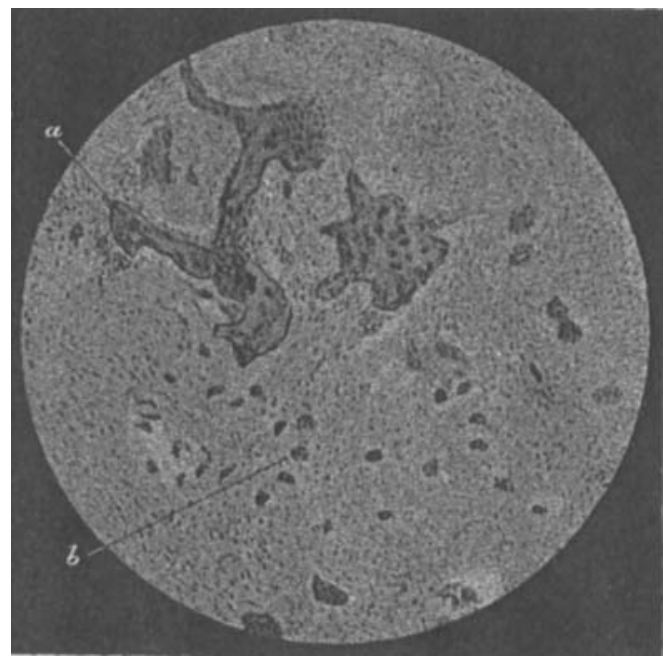

Fig. 49.-J. O. Tissue from middle of shaft of tibia. (R. Jones's Case.) (a) Bone ; (b) Osteoclasts in fibrous tissue. (Low power.)

to the cortex of the bone, but was covered by the periosteum and a layer of new periosteal bone externally. Apparently there had been a periosteal hremorrhage ; the lifted periosteum had formed a new layer of bone, which thus enclosed a blood cyst.

An exactly similar case has been described by Nové Josserand in the tibia, and Deet\% has described another in the femur.

A further type of disease, in which there is a development of large masses of tissue of a fibrous nature in the tibia, is well shown in the following case, related to me by Mr. Robert Jones, and recorded by me in the British Medical Journal.

J. O., a boy of 10, came under the care of Mr. Robert Jones in June, 1906. He had a fall upon the leg some (? six) years before, there being, it was said, no fracture. The tibia had commenced to bend after this. The middle of the shaft of the bone was very greatly thickened, and bent almost to a right angle. At this point the tibia was very greatly expanded, the expanded area being subdivided by trabeculæ (Fig. 47). An exploratory operation was performed, and the deformity corrected by the removal of a wedge of the diseased tissue. In June, 1912-six years after the operation-the leg was straight and strong, the tibia being a little thickened. A skiagram (Fig. 48) shows that there is still an area of expanded and irregularly trabeculated tissue, which shows a transverse line across it, apparently at the site of the operation.

The wedge of tissue removed was sent to me by $\mathrm{Mr}$. Jones. It was covered by a thin shell of compact bone. The deeper part consisted of fibrous tissue of varying density, with occasional spicules of bone; these showed signs of cxtensive absorption by osteoclasts, while in places there was also active deposit by osteoblasts. Small areas which,

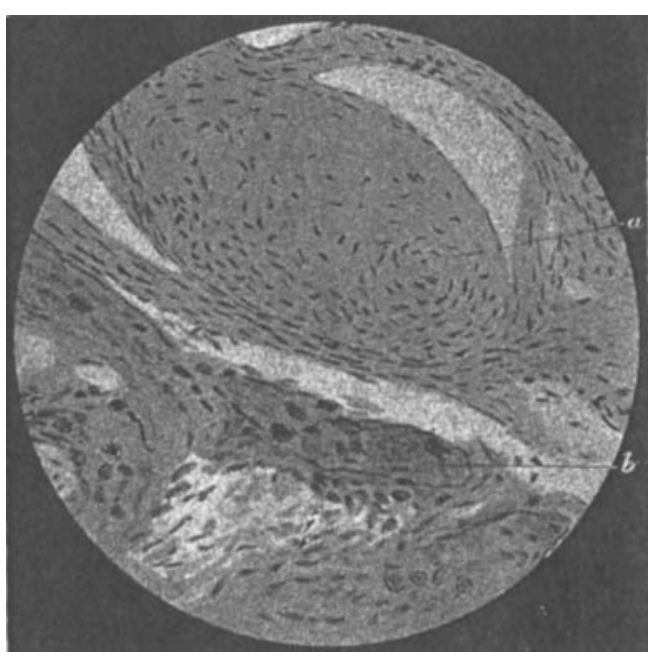

Fia. 50.-J. O. Tissue from centre of shaft of tibia. (R. Jones's Case.) (a) Well-formed fibrous tissue with whorled arrangement; (b) Bone. (High power.) macroscopically, looked like cartilage, consisted of dense fibrous tissue with a whorled arrangement. The whole tissue'twas very vascular (Figs. 49 and 50). 


\section{FIBROCYSTIC DISEASE OF THE BONES}

Warren Low showed a similar case at the Medical Society in 1910.

The patient was a boy, age 9 ; there was a swelling of the shaft of the tibia, just below the centre, which dated from an injury a month before. The soft tissue was gouged from the interior of the bone; it showed chronic inflammation ; no pus, caseous material, or dead bone was found, and no evidence of tubercle or syphilis. Progressive enlargement of the bone occurred, and further operations of the same sort were performed in each of the following two years. At the third operation the diagnosis of central ossifying myxofibroma of the tibia was made. A fracture through the diseased bone took place later. In Jan., 1914, the boy was again shown at the Medical Society. There had been gradual progress of the disease until it involved a large part of the shaft of the tibia, which was expanded, bowed forwards, and bent. Since that time $I$ understand that the diseased part of the bone has been resected.

The microscopic sections shown by Mr. Low closely resembled those obtained in the last case. They showed fibrous tissue, mostly of a cellular nature, with spicules of bone which were not confined to the peripheral part, but occurred throughout the thickness of the shaft, and which showed layers of osteoblasts upon the surface, and also osteoclastic absorption.

A specimen in the museum of University College Hospital (48) is apparently of the same nature. The case was reported by Bilton Pollard in the Transactions of the Pathological Society in $\mathbf{1 8 8 5 .}$

The patient was a little girl who injured her leg at the age of one year. Swelling and bending of the tibia commenced at $2 \frac{1}{2}$ years, and progressed until the age of 5 , when the leg was amputated, the diagnosis of sarcoma having been made. The specimen is-ropresented in Fig. 51 . The tibia and fibula are both affected, a large part of the interior of the shafts of the bones being replaced by a firm fibrous tissue containing spicules of bone. The microscopic changes are so similar to those in Mr. Jones's case that they require no further description (Figs. 52 and 53).

A case, described by Pitts and Shattock as non-calcifying plastic osteitis in the tibia, is probably of the same nature. In this case, which occurred in a woman, the upper

Fra. 51.-Tibia and fibula. (Bilton Pollard's Case. University College Hospital Muscism.)

central parts (St. Thomas's Hospital museum, 411b). part of the tibia was affected. The chief peculiarity was that the areas of bone were either not calcified at.all, or else only in their

Fibula.-Most of the cysts described in the fibula have been definitely myeloid sarcomata. There is an excellent specimen of this sort in the museum of St. Bartholomew's Hospital (471c).

The specimen consists of the lower end of the fibula of a child, showing expansion by a cyst measuring 1 in. by in., the anterior wall of which has been removed. The bony walls of this cavity are greatly thinned, and blood-clot and the remains of a whitish growth are present in its interior. Microscopic examination of the growth shows that it is a nyeloid sarcoma.

It was removed by operation from a girl, age 9, who had complained of pain in 


\section{THE BRITISH JOURNAL OF SURGERY}

the region of the growth for two years. After twelve months a swelling appeared but the child's activity was unimpaired. There was no history of injury, loss of

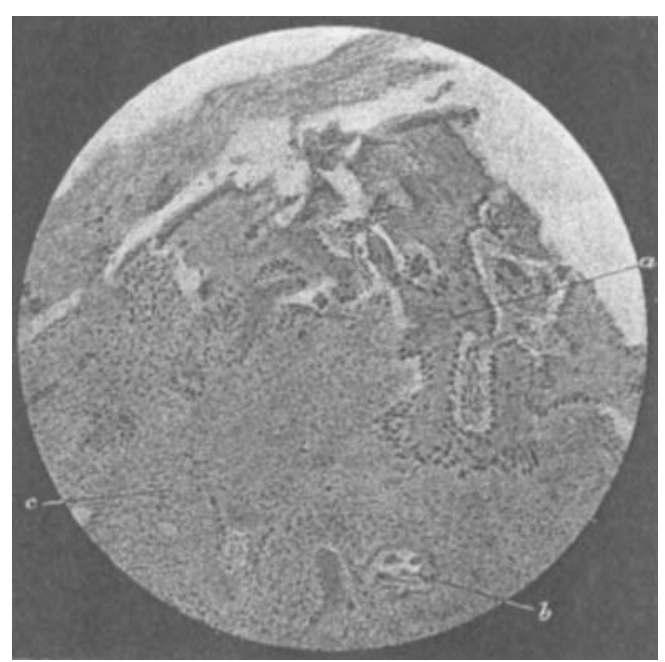

Fic. 52.-Marginal portion of diseased tissue. (Bilton Pollard's C'ase.) (a) Bone covered with osteoblasts; (b) Collection of giant cells and osteoclasts ; (c) Fibrous marrow. (Low pou'er.) consisted chiefly of cellular tissue in which were embedded giant cells; this appears to have been a myeloid sarcoma in which very little of the actual neoplasm rẹmaincd.

Bloodgood reports a case as being a healed cyst in the fibula; but as, at the explorutory operation, the expanded bone was found to be filled with normal cancellous bone, there appears to be no cridence that there had bcen a cyst at all.

Hands and Feet.--Cysts in the carpal and tarsal bones appear to be cxcecdingly rare.

Silver includes in his list one case cach in the carpal, scaphoid, and astragalus, and two in the calcancum. Boström reported a cyst in the calcaneum in a man, age 30 ; it possessed a definite fibrous-tissuc lining. I have been unable to trace the other cases. patient made an uninterrupted recoverv. Fig. 54 is from a radiograph taken before amputation.

Anschütz and Konjetzny have reported a similar case.

In a man, age 36, pain and swelling in the external malleolus followed an injury. The cyst contained some solid contents which showed the structure of a mycloid sarcoma, but the peripheral part of the cyst wall showed a complex structure which resembled osteitis fibrosa.

Fujii reports a very similar case in the head of the fibula. Tictze also reports a case in the same region, which at first sight appeared to be a simple cyst with osteitis fibrosa around; but in one recess in the cyst was a little brownish tissuc, which contained spicules of bone, but which

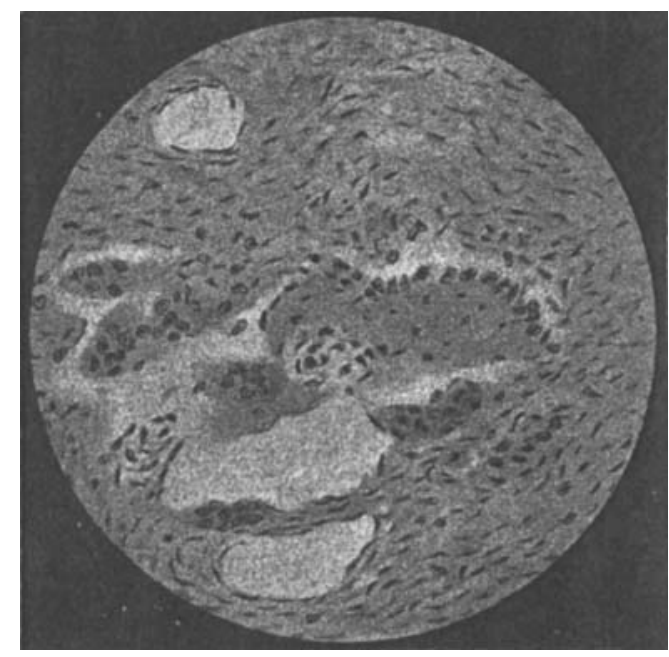

Fic. 53.- 'lissue. (Rilton Pollard's Case.) Osteoclests in neighbourhoud of a piece of bone. (High power.)

flesh, or fever, at any time. The 
Muller relates the following case.

A man had a cyst in the distal end of the fourth metatarsal bone, swelling being the first symptom. The bone was excised. The cyst was as large as a pigeon's egg, and contained a serous fluid; the interior was lined with a reddish tissue. Microscopically, there was a thin bony cortex, with narrow bone trabeculæ and wide marrow spaces; the soft tissue lining the cyst was active granulation tissue with abundant fibroblasts, well-formed vessels, and scattered osteoclasts; no cartilage was found. This cyst appears to be similar to the cysts of the tibia.

Strumpf relates a similar case.

The cyst was in the middle phalanx of the third finger of a man, age 42 . It occupied the whole shaft, and at the periphery showed bone formation and fibrous marrow. At one side of the interior, however, there was a patch of cellular tissue rich in giant cells.

Boström reports a cyst in a phalanx as due to the breaking down of a myeloma; hut, except for these cases, most of the cysts of the metacarpal and metatarsal bones and of the phalanges have been definitely myxomatous, resulting from degeneration in enchondromata. Jones reports three such cases, Blake one, Codman, Baer, and McDill one each. I have recently operated upon a woman, age 30 , in whom there were three such cysts in the first two phalanges of the little finger in association with a large enchondroma of the first phalanx. Most of the phalangeal cysts have been successfully treated by curetting.

Patella.-I have only been able to find one reported case of cyst of the patella.

In a boy, age 14 , a cyst formed around a splinter of metal which lodged in the bone. (Felten and Stoltzenberg.)

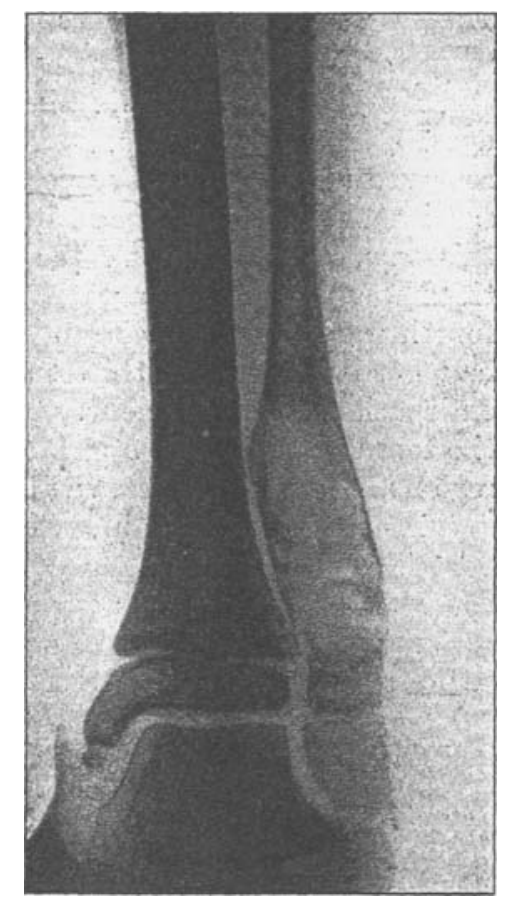

Fua. 54.-Radiograph of myeloma of fibula. (Specimen in St. Bariholomew's Hospital Míseum.)

It measured $1 \frac{1}{2}$ by 1 by $\frac{1}{2} \mathrm{cn}$.

This cyst was a small one, but is important as being the only recorded case of a simple cyst of bone around a foreign body.

Skull.-There are several cases on record of cysts of the skull associated with surrounding osteitis fibrosa. The following, reported by Ali Krogius, will scrve as a good example.

The patient was a man, age 19 , who, from the age of 13 , had noticed gradual enlargement of the right frontal bone, causing depression of the eye and failure of vision. The tumour was explored, and a cystic cavity opened; it was uncertain whether this represented an enlarged frontal sinus or not. The cyst was surrounded by a mass of yellow material like putty. The shell of bone covering this was removed, and all the diseased tissue scraped away, the dura mater being exposed. At the time the condition was considered to be a sarcoma. Twelve years later the patient 
returned; he had been quite well, the forehead had sunken in and hard bone had re-formed; vision was good; a radiograph showed the frontal sinus absent; the Wassermann reaction was negative. There was a small tender area at the internal orbital angle; this was explored, and a little more of the yellow putty-like naterial removed.

Microscopic examination of the tissue removed at the first operation showed lamellx of osteoid tissue embedded in a cellular fibrous matrix. In places this osteoid tissue was covered by a layer of osteoblasts, in places there were irregular giant cells lying in lacuna. In some of the lamella and in the fibrous tissue were calcified patches. There were some hæmorrhages and patches of pigment. The tissue removed at the second operation was similar.

Krogius collected six similar cases: One recorded by Moser in a girl, age 16, in the same situation, had been present since the age of 5 ; this was removed and diagnosed as possibly a sarcoma. A second, also diagnosed as a sarcoma by von Eiselsberg, in a man, age 23, was of eleven years' duration; this was extirpated, and the patient was well fourteen months later. The third was in a youth, age 18, recorded by Boit from Friedreich's clinic. The fourth was reported by Franke in a woman, age 4t, in whom the enlargement had been present for thirteen years; the patient was well nine years after extirpation of the tumour. The other two were reported by Wrede, one in the temporal region in a girl, age 6 , and the other in the frontal and temporal regions in a man, age 28 , the latter having existed since his sixth year.

A cyst in the skull in a case of multiple eysts will be referred to later.

Pelvis.-Fleischaner relates the case of a multilocular cyst in the ilium, containing cartilage in the wall, and co-existing with one in the femur, in a patient, age 20. Boström reports a largc cyst in the sacrum in a woman who dicd after a Cresarean section; the wall showed a composite structure, including much cartilage. Chiari reported another case of cyst of the sacrum, which had the structurc of a myeloid.

\section{MULTIPLE LESIONS.}

The eases in which eystic tumours or fibrocystic discase of more than one bonc have occurred are numerous, and apparently belong to more than onc group. An attempt will be made here to separate out certain cases which seem to have a bcaring upon the general question of the origin of bone cysts, without complicating the matter by introducing too general a discussion of discases of the bones. In particular, cascs of truc puerperal osteomalacia in which cysts may occur will be excluded.

Mr. Raymond Johnson's case of simple cysts in the humerus and radius, and Pfeiffer's of cysts in both femora, have been already described. In the following case, related to me by Capt. Bradfield, I.M.S., there were cysts of many bones, diagnosed, however, only by radiographs.

The patient was a Eurasian boy, age 6, who was admitted to the general hospital Madras, for fracture of the right fenur. The parents were healthy, and had only one other child, who was also healthy. The boy was anamic, but had had no other illness, except a rash at the age of nine months, which was cured by medicine. Radiographs showed cysts in the upper and lower ends of the shafts of both humeri ; in the right fenur there was a cyst in the upper part of the shaft, through which was the fracture; 


\section{FIBROCYSTIC DISEASE OF THE BONES}

the left femur was enlarged throughout the length of the shaft, with clear cystic patches; there was also $a$ cyst in the left tibia. The skull was asymmetrical, the forehead on the right side being prominent; a radiograph of it failed to show a cyst. There was a large capillary navus extending in the middle line from occiput to the fourth cervical vertebra.

The fracture united, but nine months later a fracture of the left tibia occurred ; there seemed to be no increase in the cystic condition in the femora, but both were more bent.

Eight months later there was a fracture of the left femur. At this time, February, 1914, the cystic formation appeared to' be less marked in the arms and in the left tibia ; in the left femur, however, it was more marked, the upper part of the bone being distinctly enlarged, and egg-shell crackling could be felt over it.

In each case the fracture occurred spontaneously whilst the child was walking ; pain was never severe, and the fractures united without difficulty. The Wassermann reaction was negative on each admission, and there were no blood changes. No treatment seemed, to have any effect except a course of mercury, which improved the general condition.

Von Mickulicz briefly reported a case of cysts in both femora, the radius, and the tibia; he gives no details to show whether these were simple cysts or whether there were masses of solid tissue around. A second case mentioned by him was subsequently reported in full by Bockenheimer; in this there was much solid tissue. Most of the other reported cases of multiple lesions have shown this combination of cysts with solid tumour formation; the following interesting case of Heineke's is an exception.

The patient was a woman, age 24. At the age of 4 she injured her left thigh and suffered from pain for a time, but the limb was left strong. For a few weeks she had suffered from rheumatic pains in the right hip and, later, in the left hip. Eleven days before admission to the clinic she felt a crack in the left hip, and the femur was found to be broken a short distance below the great trochanter. A radiogram showed a cyst at the point of fracture ; this was explored, and a part of its wall removed.

Radiographs also showed cysts (1) in the middle part of the shaft of the right femur; (2) in the tuberosities of the right humerus ; (3) in the right ilium-five small cysts, which later coalesced into one ; (4) in the left ischium ; (5) in the upper part of the shaft of the left tibia ; (6) in the first phalanx of the left great toe. All the bones cast very slight shadows. From the time when the patient was first seen, the cysts appeared to enlarge and progress for about a year; after that they remained the same, or diminished in size, during the following year. The portion of cyst wall removed shows, internally, a layer of non-nucleated fibrous tissue ; next to this, bone trabeculæ with fibrous tissue between them poor in nuclei. The bone was mostly uncalcified, but almost all the spicules showed a patch of calcification in the centre ; over most of them there was a layer of osteoblasts.

This case is of great interest as showing the development of cysts in most of the common situations at the same time, and also as showing that the development may be rapid for a time, and then ceasc.

Bockenheimer's case was as follows.

A girl, age 17, fractured her right femur in the upper third when 5 years old. At 11 pain commenced at the site of the fracture, and continued for two years, when the bone broke again. After this there was increasing deformity and shortening of the femur. The cyst was explored by von Mickulicz at 14, and an attempt made to straighten the bone by osteotomy. A cyst in the tibia was also explored at the same time. At 15 the bending of the femur recurred. At the age of 17 radiographs showed a cyst in the neck, trochanter, and upper part of the shaft of the fenur. In the tibia there was no cyst, but the bone was thick, and the distinction between compact and cancellous bone lost. 'The cyst in the femur was opened, and the shaft of the bone 


\section{j8 THE BRITISH JOURNAL OF SURGERY}

explored. The patient became collapsed during the operation, and died three hours later.

Post mortem there were no changes except in the right femur and tibia. In the fenur the marrow cavity was almost completely filled with masses of an opaque yellow substance; the cortex formed only a thin shell over this; in this material were patches of bone and cartilage. In the tibia the whole diaphysis was filled with the same material, the cortex being much thinned and replaced by it. Microscopically the changes were such as have already been described as found in the fibrocystic lesions of the femur and in fibrous lesions of the tibia.

Similar cases, in which the femur and tibia of the same side have been affected, are described by Tietzc and Röpke. In these therc were cysts in both bones, and in each case the condition arose early in life.

The following similar case of Lawford Knaggs is of great importance.

A man, age 53, fractured his right fenur by slight violence. From adolescence he had suffered from genu valgum and a swelling of the lower third of the tibia, with some bending. These had, however, given hin no trouble until a fortnight before the fracture, when there was some pain. After watching the patient for two months and taking several radiographs, Knaggs concluded that there was a new growth, and amputated the limb. Recurrence took place in the inguinal glands seven months later, leading to death. The disease in the femur extended from an inch below the head to the middle of the bone. At the site of the fracture there was complete destruction of the compact tissue on the inner side, and an infiltrating mass of the growth extending into the muscles. In the tibia the disease extended through the greater part of the length of the bone, which in its lower part was expanded. In the fibula there were two expansions, one near the upper and one near the lower end. Microscopically, the replacenent of the fat marrow by a well-marked, and in many places highly cellular. connective tissue, in which irregular ossification was going on hand in hand with bone absorption, was characteristic of the changes in those portions of all three bones which were obviously unnatural. In some parts, in addition, there was a tendency to necrosis. In certain of the most typical parts the condition described shows very active bone absorption by osteoclasts. The central portions of the trabecular of bone found in the diseased areas showed calcification. The sarcoma was spindle-celled. This appears to be a clear case of long-standing fibrous disease of the femur and tibia, with the late supervention of a sarcoma.

In the following case of Haberer's, the upper ends of both femora, the parietal bone, and the lower jaw wcre all affected. They contained eysts, and in the case of the femur, which was explored, a considerable amount of solid tumour-formation also.

The patient was a boy, whose first symptom was swelling of the lower jaw in his third year. Fractures of the right femur occurred in the fifth and eighth years, both of them uniting. In a later report, Haberer says that at the age of 13 the condition had progressed, and the boy's health was bad. There were, in addition to the disease alrcady mentioned, patches of transparency in the base of the skull ; a translucency of the upper jaw, as if this was imperfectly calcified; and cystic enlargements of the upper part of the shaft of the humerus, the middle of the shaft of the tibia, and many of the ribs.

This case was described by Haberer as osteitis fibrosa with giant-cell sarcoma formation. At the first onset, so far as the femora were concemed, the condition was similar to the ordinary type of disease in that bone, but combined with this were the lesion of the skull, apparently exactly similar to that in cases in which the discase is localized in that region, and the cyst formation in the lower jaw. Later, however; were found eysts in the humerus and tibia, exactly similar in the radiographs to those found in these situations in single 


\section{FIBROCYSTIC DISEASE OF THE BONES 59}

bone cases. Thus far this case links together many of the conditions already described. But it goes further. The discovery of the tumours of the ribs, and the microscopic examination made of a portion of tissue removed from the shaft of the right femur, gave a pathological and clinical picture which connects the case with another class, which will be next described. In the

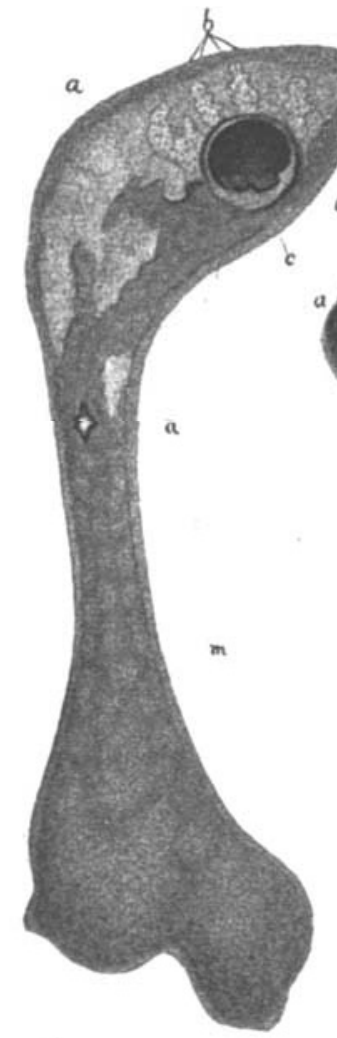

Fig. 5ó.-Femur from von Recklinghatsen's case. (a) White fibrous tissue; (b) White porous bone formed within the fibromm; (c) Cyst with dark brown slimy material. Several browi pigmented spots strewn in the yellow marrow $(m)$, and the remains of the spongiosa of the epiphysis; (i) Region of impaction. $a$

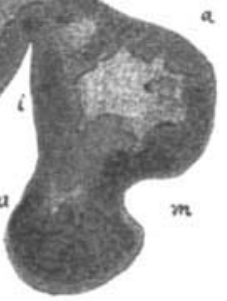

Virchow in 1891, contained a record of cases of several different classes. The following may be selected as illustrating this generalized disease.

The skeleton of a woman, age 66 , who died of pnellmonia. There was generalized hyperostosis of the skeleton, with cyst formation, enormous hyperostosis of the skull, hyperostosis and bending of the femora and right humerus, and porosity of other bones, e.g., of the ribs. The bending had not arisen from previous fractures. In the bone marrow there were patches of bone of ivory hardness, patches of spongy bone, islands of fibrocartilage, marrow tissue, and large cysts.

In this case von Recklinghausen concluded that the changes were all old, and that the active disease had long ceased. The hyperostosis and the hardness of some of the new bone formations he looked upon, not as a primary part of the disease, but rather as secondary protective changes. In fact, this case showed the appearances which might be expected in Haberer's boy if the disease should become arrested. (Fig. 55).

A man, age 40, who had been treated with mercury for syphilis, fell off a ladder, and eight days later came to the clinic with severe pain in his hip. A fracture of the femoral neck was found. Following this, there were fractures by slight violence of the left clavicle, of the shaft of the right femur, and bending of the humerus, femur, and tibia. The disease lasted one and a half years, and death took place from marasmus. Post mortem, the cortical part of the long bones was found to be converted into a finely porous substance ; the cancellous bone of the epiphyses was also altered, and contained small cysts. The marrow cavities were diminished by the thickening of the bone around. There were also myeloid sarcomata in many bones, showing as brown patches of considerable size ; in some of these lay tiny cysts, for the most part the size of a pin's head, but in one rib was a cyst the size of a pea, and in a tumour in another rib was one the size of a cherry-stone. 
This case appears to be one of multiple true myeloid sarcomata, with generalized bone changes, the latter being similar to, but not quite the same as, those of the ordinary types of fibrocystic disease.

Butlin, in 1880, described the following case as one of mollities ossium, with mycloid sarcomata of the lower jaw and rib.

The patient was a man, age 50, who was admitted to hospital for two tumours of the lower jaw, one of which had been present for seven, the other for four, years. Three months later he fractured the neck of his left femur by slight violence. After this he became steadily weaker, and died from exhaustion.

Post mortem, the tumours of the jaw, and one found in the right sixth rib, proved to be myeloid sarcomata, the stroma being spindle-celled. The femur was broken through its neck, and at the seat of fracture there existed a cavity as large as a walnut, smooth-walled, and filled with partly clotted, partly fluid and diluted blood. The whole bone was softer than usual, so that it could almost be cut with a knife, and was sawn vertically down the centre with a few strokes of a saw. Its cortex was less compact and more fatty than that of a healthy bone, while its medullary cavity was filled partly with yellow fat, but chiefly with a firm red substance resembling that which formed the myeloid growths. The right femur presented similar characters, save that the red substance was more abundant, and in its head and neck was a cavity like that in the broken bone, but filled with thin clear fluid. The right humerus was in the same condition, and its head contained an elongated cavity filled with clear fluid. The calvaria was softened, so that it could easily be bent between the thumb and the fingers of one hand, but it retained its elasticity, for it immediately regained its shape when the pressure was relaxed. Other bones examined were similarly soft and altered, except that they contained no cavities. Sections of the humerus and femora were examined. All presented characters essentially alike. The Haversian canals were widened out, and the cancellous spaces were enlarged; and all parts were filled with a tissue composed of round cells like leucoeytes, with which were mingled fat cells, or with a tissuc composed of spindle- and giant-cells like those of the myeloid tumours, but scarcely so well defined.

The specimens from this case are in the museum of St. Bartholomew's Hospital. Butlin inclined to the view that it was a case of mollities ossium, with, in addition, multiple myeloid tumours. But he also made the suggestion that there might have been a general sarcomatous disease of the bones, producing tumours in only some of them, but producing a myeloid material from which tumours might easily have developed in many of them.

The following recorded cases are of a similar kind.

A woman, when 35 , developed a tumour of the clavicle ; next year she lost the use, first of one, then of the other, arm ; and at 37 she fractured the left femur, which united, but subsequently bent and became short. She died at 39 of marasmus. Post mortem the internal organs presented no metastatic growths; the bones were soft, the cancellous bone almost completely replaced by cysts. The marrow was greyish or red, and soft. The tibia at the site of a cyst showed the structure of a giant-celled sarcoma. (Hirschibera.)

In another woman, the discase began in the third pregnancy. and death took place in one year. Post morten there were many fractures and bone deformities. The bones were extremely soft. In the left tibia there was a cyst; in addition, in the ribs, pelvis, right humerus, both femora and tibia, there were brown tumours which proved to be giant-celled sarcomata. Microscopically there was a very gradual transition from fibrous marrow into sarcoma, so that Schönenberger found it difficult to separate the two. (Schönenbergrar.)

A similar case occurred in an old woman, age 78 , in whom the changes were very widespread, and in whom there was also considerable hyperostosis. (HART.) 


\section{FIBROCYSTIC DISEASE OF THE BONES}

Another case occurred in a woman who lived nine years from the onset of the condition, and in whom tumours of two sorts were found in the bones. Some of the tumours were white and hard, and consisted of spongy bone with fibrous marrow between; others were brownish red and soft, and consisted of myeloid sarcomata. (REHN.)

In yet another case there were, with the characteristic changes of osteitis fibrosa, cysts in numcrous bones, and a series of central bone tumours. The disease commenced with an epulis of the lower jaw. Ten years later there was a large tumour of the upper jaw, which proved to be an ossifying giant-celled sarcoma. (WREDE.)

\section{SUMMARY OF CLINICAL TYPES OF DISEASE: THEIR RELATIONSHIP AND PATHOLOGY.}

Having reviewed the reported cases which may be included in the group of fibrocystic diseasc of the bones, it is now possible to classify these, and to attempt to consider their pathology and their relationship to each other. Stated as briefly as possible, the following classification may be made.

1. Simple single cysts, with perhaps some tissue of a composite nature in the walls, but with no evidence that they have arisen from myelomata. They occur in the upper end of the humerus, in the neck of the femur in young children, in the lower end of the femur, and occasionally in other bones.

2. Cysts definitely resulting from alteration in myelomata. They occur in the clavicle, radius, lower end of the femur, tibia, and fibula.

3. Cysts intermediate between these, in which scraps of myeloid tissue have been found in what was apparently an innocent cyst, with walls of composite tissue. They occur in the humerus, lower end of the femur, tibia, and fibula.

4. Cysts embedded in masses of composite tissue, usually described as fibrous osteitis. They occur chiefly in the femur, tibia, and skull.

5. "Fibrous osteitis" without cysts. It occurs in the tibia.

6. Multiple cysts.

7. Multiple lesions; some cysts, some solid tissue containing cysts, some solid tissue without cysts.

8. Myeloid sarcomata and cysts, in a diffuse discase of the bones which has caused softening and fracture.

It secms impossible to separate Groups $1,3,4,5,6$, and 7 from each other. 'There are intermediate cases which connect them, and the cases in which there are multiple lesions form another link. It may be suggested that the clinical and pathological variations found depend upon the particular characters of the bone at the site of the disease, upon the age of the patient, and upon the stage of the disease-i.e., whether it is of recent onset, and progressive or not. Groups 2 and 8 consist of cases in which there are undoubted new growths, and in which the cysts secm to result from alterations in these. Yet these also seem to be linked to the other groups by the occurrence of intermediate cases, on the onc hand linking the cysts resulting from single myeloids to the simple cysts, and on the other hand linking Group 8 with the multiple lesions in Groups 6 and 7 . In order to further investigate this point, it will be necessary to enquire into the theories which have been, or may be, put forward for the origin of bone cysts in general. 
The simple cysts occur chiefly in young subjects, and their most favourite site, the upper end of the shaft of the humerus, is in the neighbourhood of an epiphyseal line at which rapid growth takes place. The other sites in which they arc found, the lower end of the femur and the tibia, are also near important growing-points, and the occurrence of cysts in the shafts of these bones may be explained as resulting from the movement of a cyst, originally formed near the epiphyseal line, along the shaft by subsequent growth. In the upper end of the femur, as has been seen, simple cysts seem to occur only in quite young subjects. Now, during the first five years, up to the time when the cartilaginous neck of the femur becomes completely invaded by bone, the upper epiphyseal line of the femur is

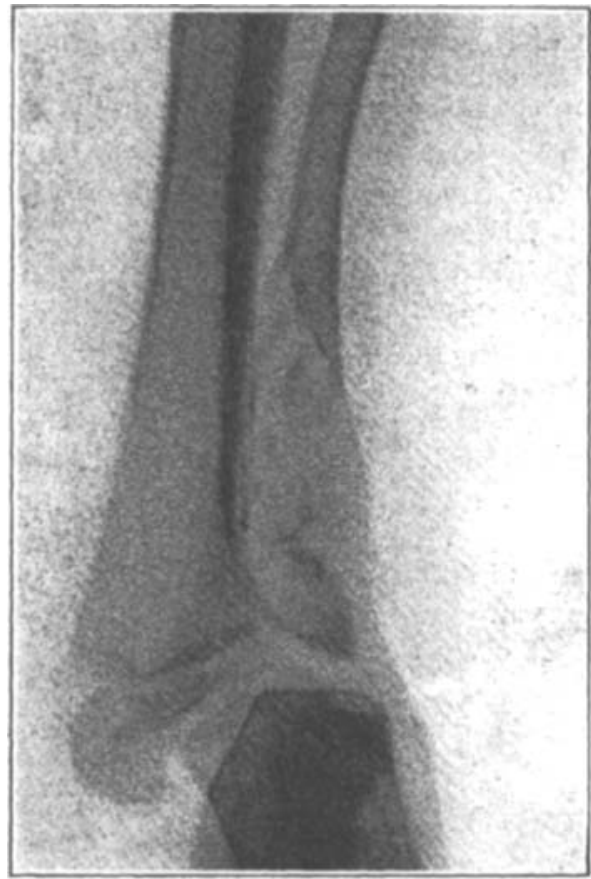

Fig. 56.--Enchondroma of lower end of fibula. an important growing-point; it is only after this time that growth at this epiphysis becomes slower. So that these cysts also may be regarded as occurring in the neighbourhood of a growing-point. The fibrocystic conditions of the upper end of the femur have been found in rather older subjects; and it may be suggested that, at a stage when growth is less active, there is a tendency for the discase to take a form in which much fibrous or fibrocartilaginous tissue is formed.

There can be no doubt that in many cases there has been a natural arrest of the disease, so that things have remained stationary for years, and that there are pathological differences between the appearances found in such an arrested case and in a case in which the disease is actively progressive. Stated briefly, the active disease shows young tissues, spindlecelled vascular fibrous tissue, hyaline cartilage, and abundant giant cells, with perhaps a cyst wall of loose texture resembling granulation tissue, or perhaps no cyst wall at all. The older inactive disease shows rather firm fibrous tissue, well formed and less vascular, fibrocartilage, few giant cells or nonc at all, and a firm fibrous cyst wall. In the first case the bone spicules show evident alterations in the shape of absorption by osteoclasts and new formation by osteoblasts. In the second case the bone is comparatively stationary, showing little or no sign of such changes. Upon such arguments as these may the differences in the pathological appearances be explained.

The question of the origin of bone cysts is a difficult one. In the first place there can be no doubt that cysts are formed definitely in myelomata, although it is not certain whether these result from the destruction of tissue 


\section{FIBROCYSTIC DISEASE OF THE BONES}

by the action of the giant cells, or by myxomatous degeneration ; the appcarance in the cysts of Group 3, with abundant giant cells in the region of the wall of the cyst, seem to suggest that these cclls take an active part in the production of the cyst. In the second place, the cysts of the phalanges seem to result, without any doubt, from myxomatous degeneration in enchondromata; and Virchow's hypothesis that other cysts resulted from enchondromata must be examined. These phalangeal cysts bear quite obvious evidence of their origin, and it may be at once stated that no recorded case of cyst in any other bone bears similar evidencc. Encapsuled enchondromata of the long bones are extremely rare. Gask's case has been already mentioned, Riedel has mentioned enchondromata in the lower end of the femur and in the tibia, McKenzie has described one in the trochanteric region, and a radiograph of an enchondroma in the fibula (there was a second at the upper end) is shown in Fig. 56. In none of these had myxomatous degeneration given rise to a cyst.

It is now recognized that cartilage may be formed anew in bone under various conditions; it is common in callus, and it was present in the wall of Lediard's case, an undoubted myeloma. The presence of cartilage in fibrocystic disease in the bones must be ascribed, therefore, rather to a metaplastic change than to the formation of an original cartilage tumour. Further, the disappearance of this cartilage, judging by the microscopic appearances, is due

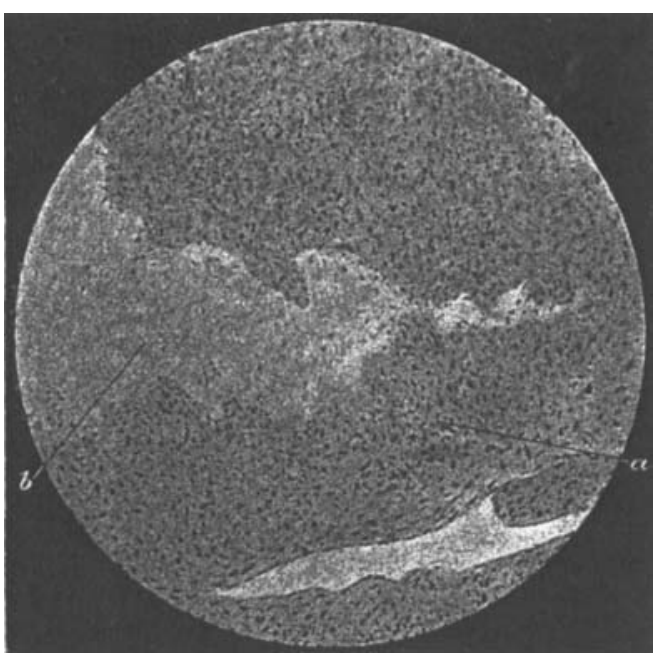

Fr6. 87.- Section of tissue forming a cystic fibromatous mass in the tibia (Eve's Case), showing a patch of degeneration, possibly the origin of a cyst. (a) Fibrous tissue, cellular; (b) Degenerated patch. (Low power.) rather to the action of the osteoclasts than to myxomatous degeneration.

Myxomatous degeneration of fibrous tissue may undoubtedly give rise to cysts in bones. Fujii has recorded a remarkable case of a man who died with a diffuse disease of the bones, which were porous and vascular throughout; there was a large cyst in one humerus and a smaller one in the femur. Fujii found definite evidence that the cysts had arisen by the softening and liquefaction of fibrous tissue. He classes the case as one of fibrous osteitis, but it presents characters which make it advisable for the present to keep it in a class apart. Eve recorded a case of cystic sarcoma of the tibia, the specimen from which is in the museum of the Royal College of Surgeons (1645c); whatever the nature of the tissue which fills the interior of the expanded tibia in this case, whether it be sarcoma or fibroma, there is definite evidence that the cysts have arisen by degeneration in it, areas of such degeneration being visible in sections (Fig. 57). Ziegler described small cysts in the neighbourhood of the joint surfaces in osteo-arthritis. He found such cysts with patches of 
cartilage, alterations in the bone, and fibrous metamorphosis of the marrow around. The cysts, he thought, were due to softening of the cartilage.

Cyst formation in bones has also been ascribed to hæmorrhage, the extravasated blood being, in theory, absorbed by the action of the giant cells. Fraenkel related a case of a cyst found in the neck of the femur in a child who suffered from infantile scurvy, which has been quoted in favour of this view. Periosteal cysts are undoubtedly of this nature; but these are very different from the true endosteal cysts, the new external shell of bone being in thcir case due to the action of the raised periosteum.

Westenhoeffer, in a discussion at the German Surgical Society, bricfly related a case of multiple small cysts in the bones of a patient who died of mercurial poisoning, and in whom there had undoubtedly been extensive decalcification of the bones.

There is not at present sufficient evidence to decide definitely how bone cysts are actually formed. There does, however, secm to be evidence that they may be formed either as the result of the action of osteoclasts, or by degeneration and liquefaction in fibrous tissue.

It must be confessed that the present state of our knowledge of the pathology of bones is not such as to enable us to classify properly these fibrocystic diseases. It would perhaps be better to state frankly that we cannot decide whether they are one disease or several; whether they are of the nature of inflammatory processes or new growths, or simply instances of disordered bone growth ; and be content with a statement of their clinical characteristics and their pathological characters, so far as these have been ascertained. For this reason, the names simple cyst, fibrous osteitis, fibrocystic osteitis, myeloid cyst, etc., are all open to objection, inasmuch as they assume in some way or other that the nature of the process is understood. If we call the condition, or conditions fibrocystic discase of the bones, we make no such assumption; and we fall in with the system which has been adopted in other organs in which obscure cystic changes occur.

If a theory is demanded, it would appear that Virchow's must be abandoncd; that there is no definite evidence that the conditions are inflammatory; and that whilst there is evidence that in some cases mycloid tumours occur, it is not feasible to claim that in every case a cyst has arisen from such a tumour. It would rather appear that there is a general disturbance in the processes of growth or alteration in the bone. That in the course of this there is (1) a fibrous metaplasia of the marrow ; (2) an excessive formation and activity of the giant cells; (3) an active absorption of bone, with coincident formation of new bone and cartilage. That in places the fibrous metaplasia may be most cvident, leading to the formation of fibrous masses ; in other places cysts may be produced, either by the action of the giant cells or by degeneration in the fibrous tissue; and that in still other places there may be abundant formation of bone-which may or may not be properly calcified-and of cartilage or fibrocartilage; whilst, last of all, the giant cells may be produced in such numbers as to form a veritable myeloma. These changes appear to have a period of activity, and then to become stationary.

Finally, in the class of case described last, in which the changes are rather different, and lead chiefly to the formation of myeloid tissues with softening of 


\section{FIBROCYSTIC DISEASE OF THE BONES}

the bones, it is possible that we see changes of the same sort ; taking, however, a more malignant course, and progressing steadily until, in some cases at least, the patient succumbs.

In conclusion, I must express my great indebtedness to the curators of the Museums of the Royal College of Surgeons, and of the various London hospitals, for permission to utilize for the purposes of this investigation the material collected therein, for permission to have drawings made of their specimens, and for the loan of microscopic preparations. I am also indebted to several surgeons for notes of cases which had not been published. These have been acknowledged in the course of the paper.

\section{REFERENCES.}

Albarran, Rev. de Chir., 1888.

Alberta, Provence Med., 1890.

Adams, Trans. Path. Soc., 1854, v, 254.

Armerini, Zeit. f. Krebsforsch., 1909, vii, 389 ; Centralb. f. Chir., 1909, xxxvi, 809.

Anschür7, Münch. med. Woch., 1908, lv, 1717 ; Ibid., 1909, lvi, 2083.

D'A reıs, Archiv. Internal. d. Chir., 1906, ii, fasc. 6 ; Centralb. f. Chir., 1900, xxxii, 602.

Baer, Discussion on Silver's Paper.

Batrle, Clin. Soc. Trans., 1804, xxvil, 290.

Beck, CARL, Archiv. f. Nlin. Chir., 1903, Ixx, 1099 ; Amer.Jour. Med. Sci., 1901, cxxi, 666.

Billati, Wien. med. Bläl., 1884, vii, 238.

BlaKe, Boston Med, and Surg. Jout., 1906, clv, 261.

Bland-Sutton, Trans. Roy. Soc. Med., 1812-13, vi, Surg. Sect., 41.

Bloodgoon, Jour. Amer. Med. Assoc., 1904, Oct. 15; Progr. Med., 1903, 191 ; Ibid., 1904, 183 ; Ibid., 1905, 275 ; Ann. of Surg., 1910, lii, 145.

Bockenheimer, Archiv. f. klin. Chir., 1908, Ixxxi, 236; Ibid., 1908, Ixxxv, 519.

Borchard, Deut. Zeil.f. Chir., 1908, xciii, 1 .

Boström, Festschr. d. Naturforscherversamml. im Freiburg, 1883, 56th Congress, 80.

Börticher, Verhand. d. deut. Gesell.f. Chir., 1004, 276.

Brade, Münch. med. Woch., 1911, lviii, No. 27, 1454.

Braun, Beil. zur klin. Chir., 1900, lii, 477.

Von BrunN, Ibid.. 1905, xlv, 344; Ibid., 1906, 1, 70.

Ruchanan, Glasgow Med. Jour., 1882, xvii, 3.10.

Butlin, Trans. Path. Soc., 1880, xxxi, 277.

CARLE, Lyons Med., 1878, No. 27.

Chinat, Wien. med. Woch., 1878, No. 9, xxviii, 204 ; Verhand. d. deut. path. Gesell., 190.1.

Cooman, Boston Med. and Surg. Jour., 1904, Feb. 25, cliii, 211.

Cons, Deut. med. Woch., 1007, Xxxiii, 570.

Colvin, Discussion on Silver's Paper.

Corsov, Ann. of Surg., 1802, April, xxxv. 505.

Cuntis, Amer. Jour. Med. Sci., 1893, cvi, 30.

Czenny, Wien. med. Woch., 1873, 894.

Davis, G. D.. Discussion on Silver's Paper.

Davidsoun, Discussion on Mönckeberg's Paper.

Deckfen, Dissert., Giessen, 1909.

Deetz, Beit. zur klin. Chir., 1900, xxvi, 120.

Dreesman, Centralb. f. Chir., 1903, xxxi, 1323.

Dumpercher, Woch. d. Wien. Aertze, 1868, No. 6.

Von Eisflsbeng, Archiv. f. hlin. Chir., 1906. Ixxxi, 20

Eumsule, Trans. Roy. Soc. Med., 1909-10, iii, Clinical, 192 ; Bril. Med.Jour., 1012, Nov. 16 ; St. Barts. Hosp. Rep., xlviii, 1912, 73 .

ENGEL, Dissert., Giessen, 1864.

Eve, Trans. Palh. Soc., 1888, xxxix, 273.

Fedden, Trans. Roy. Soc. Med., 1910-11, iv, Clinical, 139.

Felten and Stoltzenburo. Zeil. f. orth. Chir., 1912, xxx, 430.

Fleischaner, Deut. med. Woch., 1905, No. 19.

Frangenheim, Deut. Zeit.f. Chit., $1907, \mathrm{xc}, 87$.

VoL. II. -No. 5 . 
Fravke. Verhand. d. deut. Gesell. f. Chir., 1912, j, 71.

Fraenkel, Ibid., 1904.

Froriep, Chir. Kupfertafeln, 1826, Tafeln 438, 439, 440.

FusII, Deul. Zeit. $f$ Chir., 1911, exiii, 1 ; Ibid., 1912, cxiv, 25.

Garré, Monograph.

GASK, Brit. Jour. of Surg., 1913, i, No. 1, 49.

Gehring, Dissert., Jena, 1910.

Grima, Deut. Zeit. f. Chir., 1905, Ixxx, 476.

Gonerroy, These, l'aris, 1882.

Goldmans, Münch. med. Woch., 1902, xxxiv.

Gosselin, Clin. Chir., 1879, iii.

Gotrstein, Jahresber. d. Sches. Ges. Varterl. Cultur., 1903, Ixxxi, 133.

Gould, Pearce, Trans. Roy. Soc. Med, 1909-10, ii, Clinical, 194.

Vow Haberer, Archiv. f. klin. Chir., 1905, lxxvi, 539; Ibid., 1907, lxxxii, 873; Ibid., 1910, xciii, 791 ; Centralb. f. Chir., 1911, xxxviii, 33 ; Beiträge.

Vow Hacken, Wien. klin. Woch., 1908, No. 1 .

Halstead, Johns Hopkins Hosp. Bull., 1904, xv, 262.

Hart, Beit. z. path. Anat., 1904, xxxvi, 559.

I Hartmann, Beit. zur. klin. Chir., 1911, Ixxiii, 627.

Henth, Trans. Med. Soc. London, 1911 , xxxiv, 254.

Heineice, Beil. zur klin. Chir., 1903, xl, 481.

Helming, Verhand. d. deut. Gesell. f. Chir., 1902, 123 ; Centralb. f. Chir., 1902, xxix Supplement, 138.

Hirscrberc, Beit. zur path. Anat., 1889, vi, 511.

Hunt, Centralb. f. Chir., 1904.

Hugel, Münch. med. Woch., 1904, No. 14, li, 439.

Joacimisthal, Berlin klin. Woch., 1911 , xlviii, 685.

Jones and Morgan, Archives of the Röntgen Ray, 1907, xi, 316 and 342

Josserand et Bérard, Rev. de Chir., 1895, xv, 436.

Kammfrer, Ann. of Surg., 1904, xxxix, 105.

Kaposı, Jahresber. d. Sches. Ges. Varterl. Cultur., 1008, Ixxxvi, 241.

Kehr, Deut. zeit. f. Chir., 1896, xliii, 186.

Kido, Trans. Roy. Soc. Med., 1910-11, iv, Clinical, 106.

Inaggs, Lawford and Gruner, lbid., 1908-9, ii, Pathological, 26.

Косн, Archiv. f. klin. Chir., 1902, lxviii, 977.

König, F., JR., lbid., 1808, lvi, 667.

Könı, SR., Verhand. d. deut. Gesell.f. Chir., 1900, i, 174 ; Centralb.f. Chir., 1906, xxxiii, Supplement, 26.

Körte, Verhand. d. deut. Gesell.f. Chir., 1906, i, 194 ; Deut. Zeit.f. Chir., xiii, 42.

Kon.Jetzey, Beit. zur klin. Chir., 1810, lxviii ; Münch. med. Woch., 1909, 2083.

Knoaıs, Finska Läkaresällskapets Handlingar, 1913, Iv, 291.

İ̈̈ten, Archiv. f. klin. Chir., 1897, 1v, 594.

I,ABert, Allas.

Ir.dink1), Trans. Roy. Soc. Med, 1910-11, iv, Clinical, 132 : Lancet, 1911, clxxx, 736.

Lritt, Lancet, 1910, ii, 1202 ; Trans, Roy. Soc. Med., 1909-10, jii, Children, 98.

Lexen, Archiv. f. klin. Chir., 1906, lxxxi, 363 ; Verhand. d. deut. Gesell. f. Chir., 1906, Discussion.

Iow, Warken, Trans. Med. Soc. London, 1910, Nov., xxxiv, 414; Ibid., 1913-14.

McDili, Ann. of Surg., 1913, Iviii, 553.

Mackenzre, Discussion on Silver's Puper.

Mauclatre and Bernier, Archiv. Gén. de Chir., j911. Aug.

Meissner, "Zur Pathugenese der Kochencysten." Dissert., Frlangen, 1884.

VoN Mickulicz, Centralb. f. Chir., 1004, xxxi, 1323.

Murener, Deut. Zeit. f. Chir., 1908, xeiii, 328.

MöNCKF̈ERg, Verhand. $d$. deut. pah. Gesell., 1904, 232.

Moser, Beit. zur klin. Chir., 1890, xxv, 503.

Muller, Univ. Penn. Med. Bull., 1906, Sept.

Mumingy, Lockhart, Trans. Roy. Soc. Med, 1909-10, ii, Clinical, 105 ; Ibid., Children, 99.

Mynpux, Syygical Clinics of J. B. Murphy, 1913, Aug.

Nétation, Eléments de Palh. Chir., 1847, ii, 48.

Paus, Surg. Gyn. and Obst., Internat. Abstract, 1913, Dec., 635.

l'Fercy, J. F., Mrid., xvii, 536.

Pextirs, Münch. med. Woch., 1908. Iv, 1409.

Prenfrer, Beit. zur klin. Chir., 1007. liii, 473.

Prucgradt, Discussion on Franke's Paper. 


\section{FIBROCYSTIC DISEASE OF THE BONES}

Pitts and Shattock, Trans. Path. Soc., 1897, xlviii, 170.

Poliand, Bilton, lbid., 1885, xxxvi, 388.

Ponzio, Archiv. di Ortoped., 1912, xxix, 293.

Von Recklingriausen, Festschr. f. V'irchow d. Assistenten, 1891 ; Tagebl. d. Naturforscherversamml., 1889, Heidelberg, 321 ; Unterschungen uber Rachitis u. Osteomalacie, Jena, 1910.

Rehn, Beit zur klin. Chir., 1911 ; Verhand. deut. Gesell.f. Chir., 1904.

RetzLAFF, Münch. med. Woch., 1911 , lviii, 874.

RIEDEL, Verhand. d. deut. Gesell. $f$. Chir., 1906, i, 174.

RitTer, Deut. Zeit.f. Chir., 1908, xciii, 166.

Röpкe, Archiv. f. klin. Chir., 1910, xcii, 126.

Rovghton, Lancet, $1909, \mathrm{i}, 973$.

RuMPeL, Münch. med. Woch., 1907, liv., 1507.

Scmlange, Archiv. f. klin. Chir., 1887, xxxvi, 117 ; Ibid., 1893, xlvi, 373 ; Verhand. d. deut. Gesell.f. Chir., 1906, i, 173 ; Beit. z. anat. u. klin. Kenninis der Cyst, in den lang. Röhrenkn., Fests. für Esmarch, 431.

Schmeiden, Deut. Zeit.f. Chir., 1903, Ixx, 207.

SchmidT, Ergeb. d. path. Lubarsch, Ostertag. 5 and 7.

SchMoR,, Verhand. d. deut. path. Gesell., 1904 ; Ibid,, 1907.

Schönenberger, Virchow's Archiv., 1901, clxv, 189.

Silver, Amer. Jour. Orth. Surg., 1912, ix, 563.

Simmons, Boston Med. and Surg. Jour., 1900, clxi, 393.

Solly, Med.-Chir. Trans., 1844, xxvii, "Cysts in Mollities Ossium."

Sonnenburg, Deut. Zeit.f. Chir., 1879-80, xii, 314; Fortschr. a. d. Gebeile. d. Roetgenstrahlen, viii.

Stikling, Virchow's Archiv., 1890, cxix, 542.

Studeny, Arch.f. klin. Chir., 1910, xcii, 495.

Stuparick, Wien. med. Presse, 1901, No. 49.

Strumpf, Deut. Zeil. f. Chir., 1812, cxiv, 417.

TAYlor, Discussion on Silver's Paper.

Tretze, Beit. zur klin. Chir., 1906, lii, 495 ; Verhand. d. deut. Gesell. f. Chir., 1806, i, 167.

Virchow, Monatsbericht. d. kgl. Akad. d. Wissenchaften, 1876, 869 ; Virchore's Archit., $1 \mathrm{xx}$, б02.

Westernhöffer, Discussion on Mönckeberg's Case.

Wuiman, Ann. of Surg., 1904, xl, 121.

Wilms, Deut. med. Woch., 1905, xxxi, 1624.

Worlamuth, Centralb. $f$. Chit., 1903, xxxi, 1023.

Wollenberg, Zeit, f. orth. Chir., 1909, xxii, 301 ; Therap. Rundschau, 1908, ii, 773.

Wrede, Berlin med. Woch., 1911, xlviii, 616; Centralb. für. Chir., 1008, 1400 ; Discussion on Franke's Paper.

Ziegler, Virchow's Archiv., 1878, lxx, 205 ; Ibid., lxxiii, 355.

Zenon,, Arbeit. aus a. path. Institut., Göttingen, 1893 